\title{
An overview of mesoscale aerosol processes, comparisons, and validation studies from DRAGON networks
}

Brent N. Holben ${ }^{1}$, Jhoon Kim ${ }^{2}$, Itaru Sano ${ }^{3}$, Sonoyo Mukai ${ }^{4}$, Thomas F. Eck ${ }^{1,5}$, David M. Giles ${ }^{1,6}$, Joel S. Schafer ${ }^{1,6}$, Aliaksandr Sinyuk ${ }^{1,6}$, Ilya Slutsker ${ }^{1,6}$, Alexander Smirnov ${ }^{1,6}$, Mikhail Sorokin ${ }^{1,6}$, Bruce E. Anderson ${ }^{7}$, Huizheng Che $^{8}$, Myungje Choi ${ }^{2}$, James H. Crawford ${ }^{7}$, Richard A. Ferrare ${ }^{7}$, Michael J. Garay ${ }^{9}$, Ukkyo Jeong ${ }^{1}$, Mijin Kim ${ }^{2}$, Woogyung Kim ${ }^{2}$, Nichola Knox ${ }^{10}$, Zhengqiang Li ${ }^{11}$, Hwee S. Lim ${ }^{12}$, Yang Liu ${ }^{13}$, Hal Maring ${ }^{14}$, Makiko Nakata $^{15}$, Kenneth E. Pickering ${ }^{1}$, Stuart Piketh ${ }^{16}$, Jens Redemann ${ }^{17}$, Jeffrey S. Reid ${ }^{18}$, Santo Salinas ${ }^{19}$, Sora Seo ${ }^{20}$, Fuyi Tan ${ }^{12, a}$, Sachchida N. Tripathi ${ }^{21}$, Owen B. Toon ${ }^{22}$, and Qingyang Xiao ${ }^{13}$

${ }^{1}$ NASA Goddard Space Flight Center, Greenbelt, MD, USA

${ }^{2}$ Department of Atmosphere Sciences/IEAA BK 21 plus, Yonsei University, Seoul, Korea

${ }^{3}$ Faculty of Science and Engineering, Kindai University, Higashi-Osaka, Japan

${ }^{4}$ The Kyoto College of Graduate Studies for Informatics, Kyoto, Japan

${ }^{5}$ Universities Space Research Association, GESTAR, Columbia, MD, USA

${ }^{6}$ Science Systems and Applications, Inc., Lanham, MD, USA

${ }^{7}$ NASA LRC, Hampton, VA, USA

${ }^{8}$ Chinese Academy of Meteorological Sciences, China Meteorological Administration, Beijing, China

${ }^{9}$ Jet Propulsion Laboratory, California Institute of Technology, Pasadena, CA, USA

${ }^{10}$ Namibia University of Science and Technology, Windhoek, Namibia

${ }^{11}$ Institute of Remote Sensing and Digital Earth, Chinese Academy of Sciences, Beijing, China

${ }^{12}$ School of Physics, Universiti Sains Malaysia, 11800 Penang, Malaysia

${ }^{13}$ Department of Environmental Health, Rollins School of Public Health, Emory University, Atlanta, GA, USA

${ }^{14}$ NASA Headquarters, Washington, DC, USA

${ }^{15}$ Faculty of Applied Sociology, Kindai University, Higashi-Osaka, Japan

${ }^{16}$ North-West University, Potchefstroom, South Africa

${ }^{17}$ NASA Ames Research Center, Moffett Field, CA, USA

${ }^{18}$ Naval Research Laboratory, Monterey, CA, USA

${ }^{19}$ Singapore National University, Center for Imaging, Sensing and Processing, Singapore, Singapore

${ }^{20}$ Korea Polar Research Institute, Incheon, South Korea

${ }^{21}$ Indian Institute of Technology Kanpur, Kanpur, India

${ }^{22}$ University of Colorado, Boulder, CO, USA

${ }^{\mathrm{a}}$ currently at: DISTED College, Penang, Malaysia

Correspondence: Brent N. Holben (brent.n.holben@ nasa.gov)

Received: 30 December 2016 - Discussion started: 15 February 2017

Revised: 17 July 2017 - Accepted: 18 July 2017 - Published: 19 January 2018 
Abstract. Over the past 24 years, the AErosol RObotic NETwork (AERONET) program has provided highly accurate remote-sensing characterization of aerosol optical and physical properties for an increasingly extensive geographic distribution including all continents and many oceanic island and coastal sites. The measurements and retrievals from the AERONET global network have addressed satellite and model validation needs very well, but there have been challenges in making comparisons to similar parameters from in situ surface and airborne measurements. Additionally, with improved spatial and temporal satellite remote sensing of aerosols, there is a need for higher spatial-resolution ground-based remote-sensing networks. An effort to address these needs resulted in a number of field campaign networks called Distributed Regional Aerosol Gridded Observation Networks (DRAGONs) that were designed to provide a database for in situ and remote-sensing comparison and analysis of local to mesoscale variability in aerosol properties. This paper describes the DRAGON deployments that will continue to contribute to the growing body of research related to meso- and microscale aerosol features and processes. The research presented in this special issue illustrates the diversity of topics that has resulted from the application of data from these networks.

\section{Introduction}

The AErosol RObotic NETwork project (AERONET; Holben et al., 1998) has provided significant contributions to remote sensing of aerosols during the course its 24-year history. Observations have largely been utilized to validate satellite retrievals of aerosol optical depth (AOD) (e.g., Ichoku et al., 2002; Kahn et al., 2005; Remer et al., 2002; Sayer et al., 2012), characterize aerosol absorption and size distributions (e.g., Dubovik et al., 2002), and evaluate model products (e.g., Kinne et al., 2003; Sessions et al., 2015) and more recently forecasts through assimilation (e.g., Randles et al., 2017; Rubin et al., 2017) of aerosol properties. These investigations have largely been dominated by the highly accurate observations of extensive properties such as spectral AOD, and as more data became available, the intensive products retrieved from inversions of the radiative transfer equation such as a complex index of refraction and particle size distribution have come to the fore. The accuracy of the ground-based AERONET quality-assured (Level 2) point observations of aerosol optical depth is very high and therefore is considered a "ground truth" for most satellite and model comparison purposes. AOD is a direct measure of a column-integrated spectral property and can be derived from essentially an instantaneous measurement. Thus, the only uncertainty arises from calibration and contamination from outside influences such as optical and digital contamination in the instrument in some rare cases and cirrus clouds (e.g., Chew et al., 2011).
Given the accuracy of the calibration (Eck et al., 1999) and processing algorithms (Smirnov et al., 2000, and manual quality assurance assessment), the accuracy of Level 2 AOD is estimated to be $\sim 0.01$ in the visible and NIR spectrum for fully calibrated field instruments when pre- and postcalibrations have been applied. Further, analytic solutions to the relative contributions of the fine and coarse modes to the AOD are provided by AERONET through the spectral deconvolution method algorithm (O'Neill et al., 2003) and verified by Kaku et al. (2014).

The accuracy of the intensive AERONET aerosol properties (single scattering albedo, particle size distribution, and complex index of refraction) is less clear due to larger uncertainties in the inversion retrievals and difficulty in obtaining adequate verification data from other methodologies. These properties are extinction-weighted atmosphericcolumn integrated properties that exhibit different uncertainties than the wide variety of techniques associated with in situ measurements and estimates. The retrieval uncertainties of the column-integrated aerosol properties inverted by the Dubovik and King (2000) algorithm are well discussed in Dubovik et al. (2000); however, the additional uncertainty ins the measurement techniques is very difficult to assess due to atmospheric variability during the time of observations. The uncertainties associated with in situ techniques are well discussed by Reid et al. (2003, 2008b, 2005, 2006) for the size distributions of dust, smoke, and sea salt aerosols. Andrews et al. (2017) found that, provided the AERONET guidelines of only using absorption or an index of refraction data when $440 \mathrm{~nm}$ AOD $>0.4$ are adhered to, inversion products were within the stated uncertainty bounds. The accuracy of the inverted parameters is predicated upon the atmosphere being stable and spatially uniform within the measurement space of the sky radiance measuring radiometer. For example, if we assume that the aerosol is in the lowest $2 \mathrm{~km}$ of the atmosphere and the solar zenith angle is $60^{\circ}$, the AERONET observation path would be $4 \mathrm{~km}$ long and cover a horizontal distance of approximately $3.5 \mathrm{~km}$. Thus, for this particular solar zenith angle and layer height geometry example, AERONET retrievals are assuming relative uniformity in an atmospheric cylinder of $7 \mathrm{~km}$ diameter, $2 \mathrm{~km}$ vertically, and a measurement slant path of $4 \mathrm{~km}$ about the surface center point. Quality assurance algorithms and spatial averaging of measured sky radiance distributions have been utilized to minimize this uncertainty associated with the spatial variance of aerosol (Holben et al., 2006).

AERONET and other ground-based remote-sensing systems have the distinct advantage of the time domain with direct sun measurement frequencies of seconds to minutes throughout the day and in some instances at night. Nominally, the AOD sampling frequency for AERONET network measurements is $15 \mathrm{~min}$, and more recently $3 \mathrm{~min}$, intervals for sites with sufficient communication infrastructure. The measurements of sky radiance used to retrieve the inversion products are nominally taken hourly for AERONET 
but in some instances are taken more frequently such as early in the morning and late in the afternoon when optical air mass changes rapidly. Other networks such as the SKYNET network (http://atmos2.cr.chiba-u.jp/skynet/data. html; Hashimoto et al., 2012) make almucantar sky scan measurements at $10 \mathrm{~min}$ intervals. These high-frequency ground-based remote-sensing measurements allow the opportunity to assess aerosol properties diurnally and provide a higher probability of making valid aerosol observations under variable atmospheric conditions, such as in partial cloud cover and/or spatially or temporally varying aerosol. The temporal domain may be a powerful ally for assessing transport processes and in some instances a proxy for the spatial domain.

Individual ground-based systems inherently do not represent the spatial variation in aerosol properties. Thus, they complement the satellite retrievals and regional and global model predictions. Typically, a spatial-scale bridge to the ground-based measurements (including in situ) to satellite and model assessments has been through aircraft observations. Aircraft flights occur over ground-based point observations from profiles and various altitude transects extending tens, hundreds and thousands of kilometers and can provide spatial continuity during intensive field operations that enables scaling point location observations to the satellite observations and regional model simulations.

Field campaigns are of limited duration and aircraft flights are often discontinuous during the measurement campaign. The following question arises: is there a need for continuous high spatial- and temporal-resolution aerosol data that neither a single point nor airborne, satellite, or model results address? Furthermore, is there an approach that will clarify the uncertainty in comparisons of in situ and remote-sensing aerosol properties? In hindsight and with some foresight, the answers have proven to be yes and yes.

The series of Distributed Regional Aerosol Gridded Observation Network (DRAGON) campaigns began in 2011 primarily as a means to encourage collaboration between remote-sensing and in situ communities to compare measurements and retrievals of the intensive properties of aerosol particles, such as single scattering albedo (SSA), particle size distribution, and complex index of refraction. Note that earlier DRAGON-like campaigns (e.g., UAE Unified Aerosol Experiment, $\mathrm{UAE}^{2}$ - Reid et al., 2008a; and TIGERZ Giles et al., 2011) were performed to assess spatial and temporal intensive and extensive aerosol optical properties for comparison to satellite retrievals and thus provided further motivation for satellite and model intercomparisons with high-resolution ground-based measurement systems. We define a DRAGON network as a relatively high spatial density of ground-based sun photometers and other associated measurements of limited duration. Typically, these instruments are in a loose mesoscale grid with a two-dimensional spacing of tens to hundreds of kilometers for a period of 30 days or more with high-frequency sampling in min- utes (typically at 3 min intervals for AOD) during daylight hours. Contrast a DRAGON network with the overall AERONET global spatial distribution of hundreds to thousands of kilometers that has developed out of individual PI (principal investigator) and institutional contributor needs since 1993. An assessment of the published AERONET measurements from 1993 through 2011 showed very few in situ versus remote-sensing comparisons, many of which were of limited applicability (see Table 1; the measurements also available from the AERONET website under the various DRAGON campaigns: https://aeronet.gsfc.nasa. gov/new_web/dragon.html). Indeed, clearer descriptions of aerosol types beyond these five generic multimodal categories have been expressed in the more recent literature. Many investigations have provided clarity on the definition of fine- and coarse-mode aerosols in terms of the particle size and chemical composition of various aerosol types particularly from the in situ point of view. From a remote-sensing perspective aerosol typing remains difficult but progress is moving forward primarily by the assessment of the finecoarse partition, single scattering albedo, Ångström exponent (AE), and absorption AE (AAE) (O'Neill et al., 2008; Giles et al., 2012; Russell et al., 2014, among others). Table 2 is updated based in large part on contributions to this special issue and several other important studies using DRAGON data sets.

The description of the aerosol size distribution is of primary importance as a first-order physical and optical parameter corresponding to particle size and the associated concentration of variously sized particles. Coarse-mode aerosol is sometimes considered to have a particle radius of greater than 1 micron $(\mu \mathrm{m})$, and the fine mode ranges from 0.05 to $1 \mu \mathrm{m}$ (in volume distributions), although definitions vary widely. This type of classification may be generally applied for remote sensing from sun and sky scanning radiometers that use inversion schemes to retrieve aerosol properties (Dubovik and King, 2000; Nakajima et al., 1996, among others). Different definitions of fine/coarse-mode breakdown of the AOD are applied to the spectral deconvolution algorithm (O'Neill et al., 2003), while the Ångström exponent computed from spectral optical depth is a general scaling of fine/coarse optical influence, although it varies considerably as a function of wavelength for fine-mode-dominated aerosols (Eck et al., 1999). Note that the AERONET retrieval scheme of Dubovik and King (2000) reports the size in terms of particle radius, with the retrieved radius limits of 0.05 to $15 \mu \mathrm{m}$. The inflection point defining the upper limit of the fine-mode-sized particles of a retrieval lies between a 0.44 and $0.99 \mu \mathrm{m}$ radius in volume distributions that are composed of discrete particle sizes from a mixture of spheres and spheroids with a fixed shape distribution (Dubovik et al., 2006).

Generally, natural sources for coarse-mode hygroscopic sea salt aerosol are breaking waves and associated bursting water bubbles. These particles are nominally spheri- 
Table 1. Principle intensive parameters retrieved by sun and sky scanning spectral radiometers for five aerosol types. Sixteen published validations/comparisons of these retrievals against in situ measurements were made during field campaigns prior to 2010. Ra: Ramanathan et al. (2001); Re: Remer et al. (1997); H: Haywood et al. (2003); L: Leahy et al. (2007); B: Bergstrom et al. (2003); Chand et al. (2006); E: Eck et al. (2010); M: Müller et al. (2010); Mü: Müller et al. (2012); Rp: Reid et al. (2003); Ru: Reid et al. (2008b); S: Smirnov et al. (2003); Sc: Schafer et al. (2008); T: Toledano et al. (2011); O: Osborne et al. (2008); and J: Johnson et al. (2009). Note that most categories are incomplete (-), are not updated for the current inversion algorithm, and/or not relevant to total-column ambient retrievals.

\begin{tabular}{llllll}
\hline Parameter/type & Urban & Biomass burning & Dust & Sea salt maritime & Mixed \\
\hline SSA $\left(\omega_{o}\right)$ & $\mathrm{Ra}^{\mathrm{a}, \mathrm{c}}$ & $\mathrm{H}^{\mathrm{d}, \mathrm{c}}, \mathrm{L}, \mathrm{B}, \mathrm{C}^{\mathrm{a}}, \mathrm{Sc}$ & $\mathrm{T}, \mathrm{M}, \mathrm{Mü}$ & - & $\mathrm{O}^{\mathrm{d}}, \mathrm{J}^{\mathrm{d}}, \mathrm{E}^{\mathrm{a}}$ \\
Size distribution $\mathrm{d} V / \mathrm{d} \ln r, r_{v}$ & $\mathrm{Re}^{\mathrm{b}}$ & $\mathrm{H}^{\mathrm{d}, \mathrm{c}}$ & $\mathrm{Rp}^{\mathrm{c}}, \mathrm{Ru}, \mathrm{Mu}$ & $\mathrm{S}^{\mathrm{a}, \mathrm{c}}$ & $\mathrm{J}^{\mathrm{c}}$ \\
Real index $(n)$ & - & - & - & - & - \\
Imaginary $(k)$ & - & - & - & - & - \\
Asymmetry $(g)$ & - & - & - & - & $\mathrm{J}^{\mathrm{d}}$ \\
$\%$ sphericity & - & - & - & - & - \\
\hline
\end{tabular}

${ }^{a}$ Regional comparisons. ${ }^{b}$ Nakajima retrievals. ${ }^{c}$ Version $1 .{ }^{d}$ Single point. ${ }^{\text {e }}$ Surface comparison.

Table 2. The aerosol types detectable from remote-sensing (RS) techniques and compared with in situ field measurements. We show only those direct RS-in-situ comparisons. Unlike Table 1, here the aerosol type describes the properties of the aerosols rather than sources. We acknowledge that aerosol typing is difficult and still subjective and incomplete. (C: Corrigan et al., 2008; E: Esteve et al., 2012; Sc: Schafer et al., 2014, 2017). Some studies appearing below are given in the caption of Table 1.

\begin{tabular}{|c|c|c|c|c|c|c|c|}
\hline \multirow[t]{3}{*}{ Parameter/type } & \multicolumn{3}{|c|}{ Fine } & \multicolumn{3}{|c|}{ Coarse } & \multirow[t]{3}{*}{ Mixed } \\
\hline & \multirow{2}{*}{$\begin{array}{l}\text { Inorganic } \\
\text { Hygroscopic }\end{array}$} & \multicolumn{2}{|c|}{ Organic } & \multirow[t]{2}{*}{ Mineral } & \multirow[t]{2}{*}{ Organic } & \multirow[t]{2}{*}{$\mathrm{NaCl}$} & \\
\hline & & $\mathrm{B}, \mathrm{C}$ & $\mathrm{Br}, \mathrm{C}$ & & & & \\
\hline $\operatorname{SSA}\left(\omega_{o}\right)$ & $\mathrm{Sc}, \mathrm{E}, \mathrm{A}$ & $\mathrm{C}$ & - & $\mathrm{T}, \mathrm{M}$ & - & - & $\mathrm{O}^{\mathrm{d}}, \mathrm{J}^{\mathrm{d}}$ \\
\hline Size distribution $\mathrm{d} V / \mathrm{d} \ln r, r_{v}$ & $\mathrm{Sc}$ & - & - & $\mathrm{Mü}, \mathrm{Rp}^{\mathrm{c}}, \mathrm{Ru}$ & - & - & $\mathrm{J}^{\mathrm{d}}$ \\
\hline Real index $(n)$ & - & $\mathrm{H}^{\mathrm{d}, \mathrm{c}}$ & - & - & - & - & - \\
\hline Imaginary $(k)$ & - & - & - & - & - & - & - \\
\hline Asymmetry $(g$ ) & - & - & - & - & - & - & $J^{\mathrm{d}}$ \\
\hline
\end{tabular}

cal at most ambient relative humidity over the ocean, with AOD typically dominated by particles larger than $0.5 \mu \mathrm{m}$ radius. Dust particles are highly nonspherical airborne mineral soil and typically have radii on average greater than $1 \mu \mathrm{m}$, with numerous electron micrographs showing particles with lengths exceeding $10 \mu \mathrm{m}$, yet sometimes with a dimension of submicron size. These dust sources from arid and semiarid regions often originate in dried lake beds and intermittent waterways (Prospero and Carlson, 1972, among others). Other sources of coarse particles reported in the literature include diatomaceous earth from the Bodélé Depression in Chad (Washington et al., 2006; Ben-Ami et al., 2010), intensive construction in megacities, resulting in localized, highly variable, and largely unknown particle properties, dust from agricultural fields, pollen grains which are very large organic particles that quickly settle from the atmosphere, fly ash from unfiltered coal combustion (WHO, 1999), and ash from episodic volcanic eruptions. Thus, Table 2 has three categories for coarse-mode aerosol: sea salt, mineral dust (such as particles that contain hematite, causing absorption in the blue and UV spectrum, diatomaceous earth, and anthropogenic coarse particles), and pollen (organic). The chem- istry of "dust" particles is highly variable and is beyond the scope of this discussion; however, it is noteworthy that as chemical analysis of coarse particles is more geographically studied and better understood, there will be greater opportunity to assess the response of remote sensing to the properties of these particles.

The fine-mode (or accumulation-mode) aerosols are sometimes loosely referred to in the literature as either urban/industrial or biomass burning. These terms were convenient in the early days of remote sensing but are only a rough guide to our greater understanding of their diversity and properties. The range of fine-mode aerosol types that contribute to remote sensing can be rather daunting and often does not exist in a single type distribution in the atmosphere. Artaxo et al. (1994) in early work and continuing with Fuzzi et al. (2007), among many others, have made extensive investigations of the smoke aerosol generated during the burning season in the Amazon basin that includes both black carbon particles from flaming-phase burning and primarily brown carbon particles that are organic and from both flaming and smoldering combustion (Falkovich et al., 2005). Particle sizes are generally less than $1 \mu \mathrm{m}$ in radius in volume 
distributions, although a distinct coarse mode of ash aggregates and suspended soils is also present (Reid et al., 2005). Both have been shown to have very different absorptive properties from each other and from other types of particles; thus, we have added black carbon and brown carbon to Table 2, which typically range in volume median radius from 0.14 to $0.2 \mu \mathrm{m}$. Gas to particle conversion from nitrates, organic compounds, and $\mathrm{SO}_{2}$ can form fine-mode aerosols. This process is enhanced in the presence of clouds and fog. Sometimes, hydroxymethanesulfonate (HMS) may form within cloud/fog droplets when sulfur dioxide is present, whereupon after evaporation it can form large particles. These have been shown to have a variable modal range but typically have a mean volume modal radius of $\sim 0.45 \mu \mathrm{m}$; see Eck et al. (2012) and Li et al. (2014). The properties of these aerosol types require further evaluation. This complexity gives rise to three fine-mode aerosol types in Table 2: black carbon, brown carbon, and "other"; they can be distinguished in principle by ground-based sun and sky scanning radiometers by combinations of size, shape, and/or absorption magnitude.

Table 2 shows those studies that have objectively assessed all of the known direct comparisons of aerosol properties of AERONET to in situ measurements.

\section{The DRAGON campaigns}

The DRAGON field campaigns were developed in consideration of the spatial and temporal advantages and disadvantages of remote-sensing systems and in situ systems for ground-based, aircraft-based, and remote-sensing systems. In the previous section we described generally the assets available for a typical AERONET deployment. Table 3 presents an overview of the DRAGON campaigns, including the dominate aerosol type, the time frame, the approximate range of aerosol characteristics from a remote-sensing perspective, and the principle contact for each campaign. We have attempted to provide an exhaustive list up to the time of this writing, and this table will be maintained and updated on the AERONET website as new information is received.

The method of the DRAGON campaigns was to establish a high density of ground-based sun and sky scanning spectral radiometers within a local or mesoscale region to capture small-scale aerosol variations. For this discussion we present those distributions over tens to hundreds of kilometers and a time period of weeks to months. Very early studies dating back to the 1950s by Flowers et al. (1969) showed regional to continental-scale variations across the US, and in the 1980s sun photometry documented regional Sahelian aerosol loading during the drought (d'Almeida, 1986; Holben et al., 1991). The 1990s brought AERONET regional measurements to the Amazon Basin (Holben et al., 1996), the boreal forests in Canada called BOREAS (Markham et al., 1997), and southern Africa, with two campaigns called ZIBBIE (Eck et al., 2001) and SAFARI2000 (Swap et al.,
2003; Eck et al., 2003). These and other regional investigations brought tremendous knowledge of aerosol properties over regions dominated by a single aerosol type; however, they could not address the variability in small-scale regional aerosol processes. They also came largely before the massive data collection ushered in by the EOS satellite era that began with Terra in 2000 and continues today from an expanding series of spaceborne quantitative Earth monitoring platforms. Figure 1 shows the location of DRAGON field experiments relevant to this paper.

\subsection{United Arab Emirates - Unified Aerosol Experiment ( $\left.\mathbf{U A E}^{2}\right)$}

The $\mathrm{UAE}^{2}$ was established across the northern UAE with 18 AERONET sites distributed over approximately $150000 \mathrm{~km}^{2}$ including islands in the Arabian Gulf (Reid et al., 2008a). The campaign was conducted in August and September 2004 with the objective to assess the radiative properties of dust aerosols in a humid coastal environment from ground, airborne, and satellite perspectives. Sites were selected to provide characterization of Arabian Gulf, coastal, and interior desert sites from satellite product validation - especially in locations of consistent changes in the lower boundary condition (e.g., soil albedo, Case II waters). $\mathrm{UAE}^{2}$ was conducted in concert with an ongoing weather modification assessment (NCMS/NCAR) in the region. Although southwest Asia and the Middle East are often thought of as coarse-mode dustdominated aerosol environments, fine-mode aerosol particles from the petroleum industry and urban pollution contribute equally to overall AOD (Eck et al., 2008). From a product verification point of view, the $\mathrm{UAE}^{2}$ deployment provided the first conclusive piece of evidence that dust size retrievals are consistent with in situ measurements (Reid et al., 2008b) and that dust retrievals including vertical homogeneity can be further constrained by the inclusion of UV and near-infrared data (O’Neill et al., 2008).

\subsection{CALIPSO And Twilight Zone (CATZ)}

The CATZ campaign was the first AERONET Intensive Operation Period (IOP) to support CALIPSO aerosol retrievals. This was temporally synchronized with CALIPSO overflights to assess the aerosol variability within the along-track averaged CALIPSO retrieval. Up to 12 AERONET sites were placed along $230 \mathrm{~km}$ of the daytime Aqua track within the CALIPSO footprint on the Delmarva Peninsula on seven different dates from late June to mid-August 2007. Very low to high aerosol loadings occurred, which were all fine mode dominated.

\subsection{Transects: Indo-Gangetic aERosol Zone (TIGERZ)}

The TIGERZ campaign was an effort during the premonsoon of May 2008 to characterize the complex and high loading aerosol environment in the Indo-Gangetic Plain 


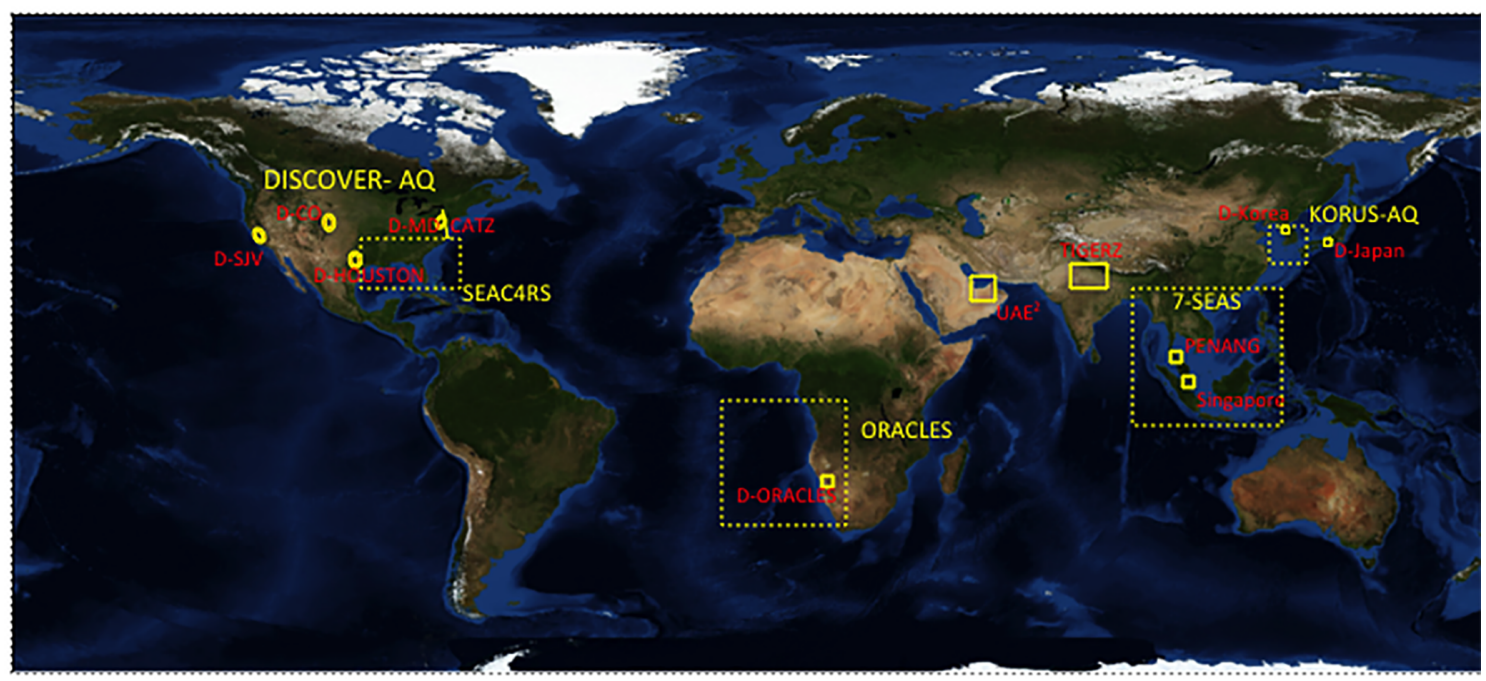

Figure 1. The distribution of DRAGON campaigns conducted from 2004 to 2016 are framed in yellow with red labels. Yellow labels indicate larger campaigns with dashed frames that include DRAGON networks.

(IGP) of northern India in support of CALIPSO satelliteborne lidar validation. The deployment of additional instruments was centered around the long-term monitoring site on the IIT campus in the industrial city of Kanpur. The premonsoon aerosol environment is characterized by regional fine-mode haze from fossil fuel emissions, mostly from coal with episodic dust events both locally generated and regionally transported from the northwest. The local Kanpur City aerosol plume was enhanced by a megawatt power plant plume and numerous coal-fired brick kilns dotting the region. Despite local strong sources, the Kanpur aerosol properties were similar to a village site $400 \mathrm{~km}$ downwind (Giles et al., 2011). Sites were established specifically to be in and very near the CALIPSO footprint, and during May, captured the spatial variability and provided validation of CALIPSO retrievals. Sites were local to the descending CALIPSO track but had a radius of up to a $300 \mathrm{~km}$ around Kanpur.

\subsection{Seven South East Asian Studies (7-SEAS)}

The 7-SEAS interdisciplinary research program has a rich history of ground-based measurements in Southeast Asia beginning in 2007, including region-wide deployments of AERONET sites throughout the Maritime Continent (Indonesia, Malaysia, Philippines, Singapore) and peninsular Southeast Asia (Laos, Thailand, and Vietnam). Overall AERONET properties can be found in Reid et al. (2013). Specific to the DRAGON concept, the AERONET program collaborated with local scientists to develop two DRAGON programs during the August-September 2012 burning season. These programs were based at the National University Singapore (NUS) for Singapore and Universiti Sains Malaysia for Penang, Malaysia.

\subsubsection{Penang}

Penang Island is mountainous with an eastern coastal plain and lies 2 to $15 \mathrm{~km}$ offshore of mainland peninsular NW Malaysia, within the Strait of Malacca. Its densely populated capital of Georgetown ( 2 million) is across the Penang Strait from industrial Butterworth, while the Malacca Strait side of the island is rural. Anchored ships, industry, and automobile traffic contribute to fossil fuel emissions, while episodic pulses of biomass burning aerosols from Riau, Sumatra, Indonesia, added to a background of sea salt aerosol within the sampled $30 \mathrm{~km}$ transect. During September 2012, Universiti Sains Malaysia staff maintained eight AERONET stations. In addition to satellite and model validation, research was conducted specific to coastal areas with these data sets utilized for air quality investigations (see Tan et al., 2015a).

\subsubsection{Singapore}

Singapore is a highly industrialized urbanized center on an island at the southern tip of the Malay Peninsula, with dimensions of approximately $30 \mathrm{~km}$ east-west by $20 \mathrm{~km}$ northsouth . The regional population including Johor Bahru is well over 5 million. Thus, fossil fuel emissions from cars, petrochemical industries, and ships constitute a major portion of the aerosol sources; however, maritime aerosol from the South China Sea and the Straits of Malacca provide a rather constant but weak background regime. Biomass burning primarily from Sumatra and Kalimantan imposes an episodic and at times massive aerosol burden on the region. The September 2012 DRAGON campaign, in collaboration with NUS' Centre for Remote Imaging, Sensing and Processing (CRISP), afforded the opportunity to assess the variability in the aerosol loading in response to local and regional sources 
from six well-distributed AERONET sites and a suite of detailed ground-based measurements across the region.

\subsection{Deriving Information on Surface Conditions from Column and VERtically Resolved Observations Relevant to Air Quality (DISCOVER-AQ)}

DISCOVER-AQ was a NASA-sponsored Earth Venture Suborbital 4-year campaign (2011 to 2014) to relate remotesensing measurements to air quality assessments at four selected sites across the United States (central Maryland; Houston, TX; San Joaquin Valley, CA; Denver Front Range Region, Colorado; https://discover-aq.larc.nasa.gov). For each campaign, this involved repeated in situ and remote-sensing ground and airborne (NASA's P-3B and King Air) measurements during most days for the duration of the campaign. This involved a series of high and low airborne transects, targeted airborne profiles, high-altitude down-looking lidar profiling, and passive remote-sensing measurements, combined with in situ ground, ground-based lidar, ozonesonde releases, and AERONET measurements configured in a mesoscale grid. As conditions allowed, flights would last for approximately $8 \mathrm{~h} \mathrm{day}^{-1}$ on most days through the $\sim 30$-day campaign. This resulted in very detailed 4-D characterizations of meteorology, aerosol, and trace gas measurements and processes that affect air quality, air quality forecasts, and their relationship to remote sensing. The AERONET DRAGON networks established for these campaigns represent the most detailed AERONET spatial characterizations to date.

\subsubsection{Maryland (Greater Baltimore) - July 2011}

This campaign selected a highly urbanized and industrial region of the mid-Atlantic that is subjected to high summertime humidity and periodic pollution buildup. The studied region was approximately $125 \mathrm{~km}$ long, following the I-95 corridor from the Washington Beltway north to the MarylandDelaware state line, and about $40 \mathrm{~km}$ wide, encompassing Baltimore, agricultural fields, suburbs, and the Chesapeake Bay. Forty-three AERONET sites were established 1 month prior to the campaign and continued monitoring for approximately 1 month after. The meteorology was classic midAtlantic for July, with daytime temperatures approaching $39^{\circ} \mathrm{C}$ on the hottest days and high humidity with daytime dew points sometimes reaching $25^{\circ} \mathrm{C}$, combined with nearly stagnant conditions with southerly flow resulting in AODs exceeding 1.0 at $500 \mathrm{~nm}$ on some days and showing considerable diurnal and day-to-day dynamics. Two cold frontal passages advected the pollution away from the region (AOD as low as 0.1 at $500 \mathrm{~nm}$ ), with subsequent gradual buildup over a period of days. The Ångström exponent (440-870 nm) during this period was typically greater than 1.5 , indicating fine-mode-dominated aerosols as one would expect in this region and season. Munchak et al. (2013) utilized DRAGON Maryland AERONET data to assess the impact of urban sur- face reflectance variations on the biases in satellite-retrieved AOD from the MODIS Dark Target algorithm. They also determined that the new $3 \mathrm{~km}$ resolution MODIS retrievals could detect AOD gradients better and make retrievals closer to clouds than the standard $10 \mathrm{~km}$ MODIS product.

\subsubsection{San Joaquin Valley, California (Bakersfield to Fresno) - mid-January to mid-February 2013}

The San Joaquin Valley occupies the southern half of California's Central Valley which is bounded by the convergence of the high Sierra Nevada range to the east and a series of coastal mountain chains to the west. The valley is flat, with intensive irrigated agriculture. The region is notable for the air quality challenges to its 3 million inhabitants: freeway corridors and intensive agriculture, including ammonia emissions and fugitive dust that contributes to particularly strong air pollution in January and February. The planetary boundary layer (PBL) is typically shallow at $\sim 1 \mathrm{~km}$ or less and adiabatically stable owing to strong radiational cooling at night resulting in frequent and persistent fog events. This, combined with various agricultural, fossil fuel, petrochemical, and largely undocumented biomass burning emissions throughout the valley, creates a complex environment for aerosol and reactive gas processes that were observed from 20 January to 15 February 2013 by DISCOVER-AQ. A DRAGON deployment of 17 AERONET stations was established from Fresno in the north to Bakersfield $175 \mathrm{~km}$ to the south and to the east at Porterville near the foothills of the Sierra Nevada to Huron $75 \mathrm{~km}$ to the west. At the time of the campaign, Porterville was heavily affected by pollutant buildup from airflow blockage by the mountains to the east. Optical depths at $500 \mathrm{~nm}$ at Porterville showed an extreme episodic and diurnal range of AOD owing to local emissions, hygroscopic growth from high relative humidity in fog, and the variable PBL height. Measured AOD values at $500 \mathrm{~nm}$ ranged from 1.2 during stagnation conditions and post-fog events to 0.1 after the valley was ventilated from passage of a cold front.

\subsubsection{Houston, Texas (Greater Houston/Galveston) - August 2013}

Houston is a massively sprawling city with a downtown center approximately $30 \mathrm{~km}$ north of Galveston and the Gulf of Mexico. A dense petrochemical industry borders the ship channel that bisects southern Houston, with numerous sources of gases and aerosols complemented by automobile emissions and other industry. Climatology showed that air quality is poorest during August; thus, like the Maryland campaign, it afforded the best opportunity to understand the processes relating emissions and air quality issues to remote sensing. The aircraft tracks were largely square racetrack circuits with six intensive vertical profiles over ground-based supersites. Seventeen DRAGON AERONET sites were used 
to characterize the column aerosol properties for 3 months (July-September). A wide range of aerosol conditions of mostly fine-mode aerosols with AOD ranging from $\sim 0.1$ to 0.7 at $500 \mathrm{~nm}$ were measured. On 23-25 August a Saharan dust intrusion moved into the region, lowering the Ångström exponent to 0.8. The region during August was characterized by high humidity and significant afternoon cloud development.

\subsubsection{Colorado - July 2014}

The northeastern plains of the front range of the Rockies formed the backdrop for the last DISCOVER-AQ campaign conducted in July 2014. The airborne and ground-based measurement campaign track included diverse landscapes and aerosol sources from central Denver to suburban Fort Collins $130 \mathrm{~km} \mathrm{~N}$ and continued $50 \mathrm{~km}$ east to rural Greeley feedlots. The track turns south $30 \mathrm{~km}$ to Platteville, which is dominated by irrigated crops and intense fossil fuel exploration and extraction. The track is closed by returning to Denver $40 \mathrm{~km}$ to the southeast. High temperatures and intense solar radiation characterized July 2014. Aerosol optical depths averaged 0.2 at $500 \mathrm{~nm}$ and day-to-day variations were typically small; however, several days of fine-mode aerosol events elevated the AOD to $\sim 0.4$.

\subsection{DRAGON-NE Asia - Korea, Japan}

Northeast Asia faces arguably the most severe air quality issues on the planet owing to the very high population density coupled with high levels of industrialization and, additionally, its position downwind of major dust source regions. These contribute to significant trans-boundary aerosol transport compounded by emissions from several megacities in the region. Given the AERONET limitations for retrievals with low uncertainty (AOD $>0.4$ at $440 \mathrm{~nm}$ ) for complex refractive index retrieval products, NE Asia routinely experiences aerosol loading that exceeds those limitations on most days; thus, investigations of the spatial and temporal variations in single scattering albedo in addition to AOD are possible. The following two campaigns called DRAGON-KOREA and DRAGON-JAPAN operated from March to June 2012. The NE Asia DRAGON campaigns did not have a significant airborne component; thus, the emphasis was on assessing the spatial and temporal variations in aerosol optical properties. Numerous opportunities occurred for satellite and model validation under a variety of aerosol gradients.

\subsubsection{DRAGON-KOREA}

Seoul was the focus for half of the 22 AERONET surface stations deployed from March to June 2012, including five permanent sites in South Korea with long-term records. Seoul is a megacity of 25 million (metropolitan region) spread across a landscape of the Han River plains, hills, and low-elevation forested mountains. Industry and fossil fuel power generation contribute emissions to a significant pollution aerosol loading in addition to aerosol advected from China. South Korea in general is a landscape that is challenging for satellite retrievals of AOD due to significant variation in background surface reflectance and a varied topography ( $\sim 70 \%$ mountainous, mostly forested) and variability in aerosol properties (fine and coarse). A decision was made to expand the network in spring 2012 to a regional or mesoscale network to further assess the impact of transported aerosols from across the Yellow Sea and from Seoul; this was done by including sites on the west coast, in the interior and the east and south. $\mathrm{AOD}$ at $500 \mathrm{~nm}$ from regional sites had daily values ranging from $\sim 0.2$ to 1.5 , while sites in Seoul varied from $\sim 0.5$ to 2.1 during episodic aerosol events.

\subsubsection{DRAGON-JAPAN}

Osaka, Japan, was the focus of a DRAGON campaign with eight AERONET sites; this was coincident in time with the DRAGON-KOREA campaign from March through June 2012. Osaka is a megacity of very dense urban development that is bounded by low mountains on three sides and Osaka Bay to the south (see Sano et al., 2016). Industry and transportation emissions are sources of the dominant background aerosol loading, and, as in Seoul, episodic coarsemode dust and transported fine-mode industrial aerosols were observed during the 4-month intensive measurement period. Owing to two nearby mountain sites, boundary layer assessments were possible and were also facilitated by a mobile handheld sun photometer.

A second DRAGON network of six AERONET and one SKYNET sites on the small $\left(326 \mathrm{~km}^{2}\right)$ rural western island of Fukue captured the dynamics of transported fine-mode aerosol properties, while an airborne campaign measured in situ gas chemistry from these events (Hatakeyama et al., 2014). Historically, many researchers have used Fukue Island to identify long-range transported aerosols (Takami et al., 2013). Sano investigated AOD at the site in 2003 (Sano, 2004). Measurements showed periodic high-AOD days that may be due to transported anthropogenic aerosols and Asian dust events from the continent. Part of the DRAGON-Fukue network was maintained until 2013.

\subsection{Studies of Emissions and Atmospheric Composition, Clouds, and Climate Coupling by Regional Surveys (SEAC ${ }^{4}$ RS)}

The SEAC ${ }^{4}$ RS mission (Toon et al., 2016) was a combined airborne and ground-based effort to assess aerosols and trace gas chemistry processes. The objective necessarily required knowledge of surface and boundary layer meteorology to assess sources of aerosols and trace gasses. The airborne implementation was changed from SE Asia (Maritime Continent) to the southeast US regional assessment of aerosol and trace gas chemistry processes in 2013, after permission to utilize 
airfields in SE Asia was not granted. This change in locations represented a major challenge and a significant scaling up from a mesoscale to a regional-scale ground-based aerosol network. It also provided an opportunity to overlap with the Houston DISCOVER-AQ DRAGON network (12 sites in $\sim 60 \times 60 \mathrm{~km})$ with a regional-scale SEAC ${ }^{4} \mathrm{RS}$ network of (30 sites in $\sim 1000 \times 2000 \mathrm{~km}$ ). Both networks operated at full density from August through October 2013. About 50\% of the SEAC ${ }^{4} \mathrm{RS}$ sites remain in operation as of 2017 to provide long-term context for the program. Toon et al. (2016) provides a detailed overview of the SEAC ${ }^{4} \mathrm{RS}$ program results. The NASA DC-8 with in situ aerosol sampling instrumentation and the 4STAR airborne sun photometer provided regional- and continental-scale transects that have been compared to the ground-based measurements (Reid et al., 2017).

Additionally, another airborne and ground-based field campaign occurred during this time period called Southeast Nexus (SENEX; Warneke et al., 2016) that emphasized volatile organic compounds (VOCs) and aerosol precursors. This campaign was focused on Alabama, Georgia, and northern Florida. The regional network by its size captures the range of aerosol properties one would expect over the southeast US, including transported dust from west Africa, biogenic aerosols created from VOCs, fossil fuel emissions, coastal maritime aerosols, and biomass burning transported from fires in the western US.

\subsection{KORUS-AQ}

Similarly to the DISCOVER-AQ campaigns, a focused airborne campaign called KORUS-AQ was conducted across South Korea from 1 May to 12 June 2016 by the National Institute of Environmental Research (NIER) and NASA. In situ and remote-sensing resources were on board three aircraft flying from the near surface to $\sim 8500 \mathrm{~m}$ profiling the atmosphere in three dimensions for up to $8 \mathrm{~h}$ on approximately 20 days. This campaign was heavily supported by a DRAGON mesoscale network of 21 advanced AERONET Cimel photometers; most had solar and lunar AOD retrievals as well as the experimental hybrid sky scans designed to allow the retrieval of aerosol radiometric and microphysical optical properties throughout the day. AERONET results for the lunar AOD and retrievals from hybrid scans are undergoing evaluation at the time of writing. It is noteworthy that two over-water oceanographic platforms provided aerosol and normalized water leaving radiances over two sites in the Yellow Sea during this time in support of ocean color investigations. Additionally, two ships had Microtops sun photometers that were calibrated at GSFC to be consistent with AERONET reference instruments. Furthermore, supporting the KORUS-AQ campaign there was a high spectralresolution lidar (HSRL) onboard the DC-8 and ground-based lidars as well as several contributing SKYNET PREDE sunsky scanning spectral radiometers.
In addition, a regional-scale campaign of ground-based remote-sensing and in situ measurements upwind and downwind of South Korea was conducted during this period. This included the Institute of Remote Sensing and Digital Earth SONET network, AERONET, and the China Aerosol Remote Sensing NETwork (CARSNET; Che et al., 2009, 2015) Cimel Sun-sky radiometer networks in NE China that contributed 20 stations focused eastward from Beijing and south to Shanghai. In collaboration with the Institute of Remote Sensing and Digital Earth of the Chinese Academy of Sciences and the University of Maryland, an airborne in situ aircraft-based study of the chemical composition of the atmosphere was also conducted during this period.

Coincidentally, an enhanced network of eight AERONET sites was distributed across Japan from Fukuoka in the south to Sapporo in the north. This network augments the extensive SKYNET network of sun-sky radiometers in Japan that provides similar aerosol observations to AERONET but also collocated lidar profiling and, in some supersite locations, in situ particle observations. Since there is overlap at some of the AERONET and SKYNET sites in South Korea and Japan, a unique and comprehensive comparison is planned between the networks.

The greater KORUS campaigns extensively sampled finemode aerosols from locally and regionally transported industrial and urban sources, biomass burning from Siberian fires, and regionally transported coarse-mode-dominated dust that strongly affected all countries on 5 May 2016 and to a lesser extent on several other days during the campaign. All aerosol types except for the Siberian biomass burning aerosols were also sampled during research aircraft flight days. The opportunity to assess accuracies and limitations of multiple satellite and AERONET retrievals and aerosol model forecasts for a variety of aerosol types and cloud and humidity conditions is expected to increase our understanding of the processes that govern air quality issues in NE Asia.

\subsection{ObseRvations of Aerosols above Clouds and their intEractionS (ORACLES)}

The NASA venture class suborbital program (ORACLES) is an ongoing airborne campaign focused on biomass burning aerosol emissions from southern central Africa transported over the South Atlantic to assess the aerosol-cloud interaction over the persistent stratocumulus deck from August through September 2016; it is planned for repeats in 2017 and 2018 (Zuidema et al., 2016). Approximately 15 AERONET sites from Mozambique, Zambia, Angola, Namibia, South Africa, St. Helena, and Ascension Island are providing regional context of aerosol properties from source to receptor sites for the campaign. Additionally, a tightly focused DRAGON network (seven sites in $20 \times 30 \mathrm{~km}$ grid) was set up on the central Namibian coast to assess the impact of aerosols on coastal fog and quantify any influence fog may play in the aerosol size distribution in this arid region. 
Table 3. DRAGON campaign summaries. D: dust; FF: fossil fuel; B: biogenic; BB: biomass burning; M: maritime. Because of the time period of measurement and the number and location of instruments and variable aerosol types transported by synoptic-scale meteorology, AOD and particularly SSA averages are approximate. Most campaigns are referenced at: https://aeronet.gsfc.nasa.gov/new_web/campaigns.html, where DRAGON data sets are also available with detailed point of contact (POC) information.

\begin{tabular}{|c|c|c|c|c|c|c|c|}
\hline Campaign & Date & $\begin{array}{l}\text { Location } \\
\text { lat/long }\end{array}$ & $\begin{array}{l}\text { AERONET } \\
\text { sites }\end{array}$ & $\begin{array}{l}\text { Aerosol } \\
\text { source }\end{array}$ & $\begin{array}{l}\sim \mathrm{AOD}_{440} \\
\text { range }\end{array}$ & $\sim \mathrm{SSA}_{440}$ & POC \\
\hline $\mathrm{UAE}^{2}$ & Aug-Sep 2004 & $\begin{array}{l}\text { UAE } \\
24^{\circ} \times 54^{\circ}\end{array}$ & 16 & $\mathrm{D}, \mathrm{FF}$ & $0.1-0.8$ & 0.93 & Reid/Holben \\
\hline CATZ & Jun-Aug 2007 & $\begin{array}{l}\text { USA } \\
39^{\circ} \times-76^{\circ}\end{array}$ & 24 & $\mathrm{M}, \mathrm{B}, \mathrm{FF}$ & $0.1-0.8$ & 0.96 & Holben/AERONET \\
\hline TIGERZ & May-Jun 2008 & $\begin{array}{l}\text { India } \\
26^{\circ} \times 80^{\circ}\end{array}$ & 8 & $\mathrm{D}, \mathrm{BB}$ & $0.3-1.2$ & 0.88 & Holben/Tripathi \\
\hline \multicolumn{8}{|l|}{ 7-SEAS } \\
\hline PENANG & Jul-Sep 2012 & $\begin{array}{l}\text { Malaysia } \\
5^{\circ} \times 100^{\circ}\end{array}$ & 8 & $\mathrm{FF}$ & $0.3-2.0$ & 0.96 & Holben/Lim \\
\hline Singapore & Aug-Sep 2012 & $\begin{array}{l}\text { Singapore } \\
1^{\circ} \times 104^{\circ}\end{array}$ & 6 & FF & $0.2-1.5$ & 0.94 & Holben/Salinas \\
\hline \multicolumn{7}{|c|}{ DISCOVER-AQ } & Crawford \\
\hline Maryland & Jun-Aug 2011 & $\begin{array}{l}\text { USA } \\
39^{\circ} \times-77^{\circ}\end{array}$ & 43 & FF, B & $0.1-0.8$ & 0.98 & Holben/AERONET \\
\hline $\begin{array}{l}\text { San } \\
\text { Joaquin }\end{array}$ & Jan-Feb 2013 & $\begin{array}{l}\text { USA } \\
37^{\circ} \times-120^{\circ}\end{array}$ & 16 & FF & $0.1-1.3$ & NA & Holben/AERONET \\
\hline Houston & Sep 2013 & $\begin{array}{l}\text { USA } \\
30^{\circ} \times-95^{\circ}\end{array}$ & 18 & FF & $0.1-0.3$ & $0 . \mathrm{NA}$ & Holben/AERONET \\
\hline Colorado & Jul 2014 & $\begin{array}{l}\text { USA } \\
40^{\circ} \times-105^{\circ}\end{array}$ & 13 & FF, BB & $0.1-0.3$ & NA & Holben/AERONET \\
\hline D-KOREA & Mar-May 2012 & $\begin{array}{l}\text { South Korea } \\
36^{\circ} \times 127^{\circ}\end{array}$ & 22 & FF, D & $0.1-1.3$ & 0.98 & J.Kim/Holben \\
\hline D-JAPAN & Mar-May 2012 & $\begin{array}{l}\text { southern } \\
\text { Japan }\end{array}$ & 15 & FF, M, D & $0.1-1.3$ & 0.98 & Sano/Holben \\
\hline $\mathrm{SEAC}^{4} \mathrm{RS}$ & Aug-Sep 2013 & $\begin{array}{l}\text { SEUS } \\
33^{\circ} \times-87^{\circ}\end{array}$ & 24 & $\mathrm{FF}, \mathrm{B}, \mathrm{BB}, \mathrm{M}$ & $0.1-0.7$ & 0.95 & Toon/Holben \\
\hline $\begin{array}{l}\text { KORUS- } \\
\text { AQ }\end{array}$ & & & & & & & Crawford \\
\hline Korea & May 2016 & South Korea & 22 & $\mathrm{D}, \mathrm{FF}, \mathrm{M}$ & $0.2-1.0$ & 0.91 & J.Kim/Holben \\
\hline Japan & May 2016 & $\begin{array}{l}\text { Japan } \\
35^{\circ} \times 135^{\circ}\end{array}$ & 7 & FF, D & $0.1-0.8$ & 0.94 & Sano/Holben \\
\hline China & May 2016 & $\begin{array}{l}\text { China } \\
40^{\circ} \times 116^{\circ}\end{array}$ & 11 & FF, D & $0.1-1.2$ & 0.89 & Z. Li/Che \\
\hline ORACLES & Aug-Sep 2016 & $\begin{array}{l}\text { Namibia } \\
-22^{\circ} \times 14^{\circ}\end{array}$ & 7 & $\mathrm{FF}, \mathrm{D}, \mathrm{BB}, \mathrm{M}$ & $0.1-0.5$ & 0.84 & Holben/Knox \\
\hline
\end{tabular}

\section{Summary of the special issue contributions}

Three important research areas have emerged as a result of the DRAGON campaigns: (1) in situ and remote-sensing aerosol properties comparisons; (2) aerosol process studies; and (3) satellite and model validation studies. The first DRAGON-like campaigns focused in part on in situ versus remote-sensing comparisons of aerosol optical, radiative, and microphysical properties. Although some of the associated publications both pre- and postdate this issue, they do merit a brief discussion. Schafer et al. (2014) showed an average difference of $\sim 0.01$ between in situ SSA from aircraft profiles compared to AERONET-based retrievals for the DISCOVER-AQ MD DRAGON data set in July 2011. Sawamura et al. (2014) used the diversity of airborne and ground-based aerosol observations including the DRAGON measurements as a reference to intercompare project observations to HSRL radiative and microphysical properties. They found better agreement within the specified uncertainties using the remote-sensing techniques compared to the airborne in situ observations. Schafer et al. (2018) has made comparisons of in situ measured size distributions 
from the multiple DISCOVER-AQ airborne profiles to the DRAGON AERONET sun photometer retrievals. Comparisons of rehydrated in situ measurements integrated vertically to the ambient retrieved remote-sensing observations showed relatively good quantitative agreement based on approximately 40 flights coincident in time and space with the ground-based measurements. Sawamura et al. (2017) used DRAGON AERONET (California and Houston) to evaluate HSRL-2 and airborne in situ AOD measurements.

Process studies have also broadened the research horizon possible from these data sets, some of which appear in this special issue. For example Eck et al. (2014) used the DISCOVER-AQ Maryland DRAGON network observations to study the effect of non-precipitating cumulus clouds on AOD in adjacent regions on a horizontal scale of a few kilometers. They found that on some days, the Ångström exponent and size distribution were relatively constant while AOD was significantly enhanced (sometimes doubling in less than $1 \mathrm{~h}$ ) near moderately sized cumulus clouds. These results were corroborated by airborne lidar and airborne in situ measurements. This has potential implications for the need for a better understanding of small-scale high temporal variations in aerosol-cloud processes and potential particle formation in clouds.

Much of the research activity with the DRAGON campaigns focused on air quality, relating remote-sensing parameters to surface $\mathrm{PM}_{10}$. Seo et al. (2015) analyzed the DRAGON-KOREA 2012 database, testing various linear models that include boundary height and effective radius to surface $\mathrm{PM}_{10}$ measurements in the vicinity of Seoul for the winter and spring and also for long-term measurements. They found the best relationship in the winter, owing to well-mixed aerosol layers, while the poorest relationships occurred during the spring when long-range aerosol transport stratified the aerosol profile.

The DRAGON-Asia campaigns were used to broadly describe trans-boundary advection of aerosols as a DRAGONscale network in Osaka was imbedded in a regional-scale network over southern Japan (Sano et al., 2016). This analysis showed that, during episodic long-range trans-boundary transport, aerosol loading was highest in the west of Japan but highly variable in space and time both for fine- and coarse-mode aerosol events. The long-range trans-boundary aerosols during this period were shown to follow the NCEPderived 700 to $850 \mathrm{mb}$ wind vectors. Sano et al. (2016) investigated the variability in AOD under clean and polluted days in Osaka using DRAGON network measurements. They also detailed aerosol transportation over the city using high spatial- and temporal-resolution measurements by DRAGON-Osaka. Owing to two nearby mountain sites, boundary layer assessments were possible, facilitated by nearby DRAGON-Osaka and AERONET stations. The DRAGON-Fukue instruments did not capture the intense 1011 March fine-mode event due to cloud contamination. However, the authors successfully measured the event by judi- ciously timed, handheld Microtops-II sun photometer observations (Nakata et al., 2016). The value of AOD at $440 \mathrm{~nm}$ was over 2. Takami et al. (2013) reported a particle composition of less than $1 \mu \mathrm{m}$ diameter by Aerodyne's aerosol mass spectrometer and that the most abundant components were $\mathrm{SO}_{4}^{2-}, \mathrm{NH}_{4}^{+}$, and $\mathrm{OC}$ during the event (Kaneyasu et al., 2014).

Tan et al. (2015b) investigated the ability to use surfacebased measurements to predict AOD in the cloudy tropics of Penang, Malaysia, where data gaps can be frequent and persistent. His predictive model had an $r^{2}$ of 0.68 compared to actual measurements of AOD from the DRAGON network.

By far the largest application of the DRAGON data sets has been in the validation of satellite data. Most synoptic-scale validation teams assume a spatial uniformity about a ground-based control point, often citing the Anderson et al. (2003) nominal scale length of $100 \mathrm{~km}$. Frequently, queries are made about the spatial representation of AERONET sites, for which there is no simple answer due to the proximity to aerosol sources and local and synoptic meteorology. The DRAGON campaigns have provided a better understanding for some specific circumstances that provide for a better assessment of the spatial resolution of various satellite products and also of high- and low-resolution model assessments. Prior to this issue, Munchak et al. (2013) noted the new Collection 6 MODIS $3 \mathrm{~km}$ AOD product could potentially assess local aerosol gradients missed by the standard $10 \mathrm{~km}$ resolution product. They used the MD DISCOVER-AQ airborne high spectral-resolution lidar and MD DRAGON data sets to assess the fidelity of the $3 \mathrm{~km}$ AOD product, finding improvement over the coarseresolution product but some additional variability due to the complexity of urban cover types. Kim et al. (2016) used the DRAGON- NE Asia networks to refine the single scattering input to a single channel AOD retrieval model used with the GEO COMS Meteorological Imager (MI). They note that the surface-based inputs from DRAGON significantly improved the model to predict AOD, thereby reducing previous overestimates.

The Ozone Monitoring Instrument (OMI) on board Aqua has been a pioneering instrument to retrieve SSA and AOD from space in the UV spectrum. Jeong et al. (2016) have used the DRAGON NE-Asia data set in an optimal-estimation procedure that provides error estimates while simultaneously retrieving inversion products. This method was shown to compare better to the ground-based measurements than the OMI operational retrieval. From this validation, the authors identified the parameters that most affected the AOD and SSA retrieval accuracy.

In a comprehensive comparison of the high temporalresolution Geostationary Ocean Color Imager (GOCI) and polar orbiting VIIRS and MODIS instruments, Xiao et al. (2016) used DRAGON NE-Asia and additional AERONET observations in 2013, which encompassed a broad range of conditions from low to high aerosol loading. 
Their analysis suggests that the satellite products do a better job of tracking aerosol variability on a day-to-day basis than tracking the high-resolution spatial variability.

Choi et al. (2016) used the DRAGON NE-Asia data sets to evaluate the GOCI AOD retrievals using the improvements to the GOCI Yonsei Aerosol Retrieval (YAER) algorithm. The algorithm makes retrievals over the Yellow Sea that often have Case II waters (highly turbid from sediment) as well as the highly variable South Korean landmass reflectances during periods with highly variable aerosol types and concentrations. GOCI YAER AOD correlated very well with AERONET but showed lower skill with the Angström exponent, fine-mode fraction, and SSA.

Garay et al. (2017) have assessed the current $17.6 \mathrm{~km}$ resolution AOD products against multiple diverse DRAGON data sets collected around the world. They found that $75 \%$ of the data fell within 0.05 of the AERONET surface-based measurements. They document the development and assessment of a prototype version of high-resolution $(4.4 \mathrm{~km})$ retrieval products compared to the same DRAGON data sets.

\section{Conclusions}

The DRAGON campaigns afford the opportunity to observe and assess aerosols for a variety of aerosol types and meteorological conditions. Sixteen multi-month mesoscale DRAGON campaigns were conducted and described that measured and/or retrieved intensive and extensive aerosol properties at high spatial and temporal resolution. The results shown in these studies challenge the long-held assumptions of large-scale aerosol spatial uniformity as too simplistic and provide data for the improvement of accuracies of higher-resolution satellite and model retrievals; they also afford a deeper understanding of aerosol process studies. From the DRAGON campaigns, we now know that (1) in situ and ground-based remote sensing of SSA has differences averaging $\sim 0.01$ in the mid-Atlantic US; (2) rapid aerosol-cloud interactions occur and can be detected with high-resolution remote sensing at scales of a few kilometers; and (3) finerresolution satellite products can capture the mesoscale spatial variability in aerosol although they also show that modifications to both satellite and model algorithms and assumptions may be necessary in order to achieve the required accuracy of these finer resolutions.

The unique opportunities for the validation of high spatialresolution satellite aerosol retrievals and the assessment of regional model estimates of aerosol optical, radiative, and microphysical properties are only beginning to be examined. The DISCOVER-AQ and KORUS-AQ campaigns in concert with in situ surface and airborne measurements provide for detailed comparison with and assessment against remotely sensed aerosol properties, and further results are expected. The papers presented in this issue demonstrate the variety of research opportunities and set the stage for new applications such as nighttime lunar mesoscale AOD assessments from the most recent KORUS-AQ and ORACLES campaigns, and also for future DRAGON networks.

Data availability. The AERONET data described in this publication and the DRAGON special issue represent Version 2 processing and are publicly available from the AERONET website data tools: https://aeronet.gsfc.nasa.gov/cgi-bin/webtool_ opera_v2_new and https://aeronet.gsfc.nasa.gov/cgi-bin/webtool_ opera_v2_inv for AOD and inversion products, respectively. Note that Version 3 processing will be available from the AERONET website beginning in 2018. The long-term coincident Version 2 database will be updated through 2018.

Competing interests. The authors declare that they have no conflict of interest.

Special issue statement. This article is part of the special issue "Meso-scale aerosol processes, comparison and validation studies from DRAGON networks". It is not associated with a conference.

Acknowledgements. All of the AERONET scientists and technical staff have contributed to all phases of the DRAGON-related campaigns since 2004. Their efforts have been fundamental to the concept, data collection, and analysis of the DRAGON data. Those not named as coauthors include Wayne Newcomb, Amy Scully, Oleg Dubovik, Don Ho, Alex Tran, Jon Robriguez, and Jason Kraft. Each campaign had a significant non-NASA team of which the PI lead is named in Table 3 and is a co-author but was supported by their own team and institution. For AERONET support, we wish to thank the EOS Project Science Office and the Radiation Sciences Program at NASA HQ. We thank the Global Change Observation Mission - Climate project by JAXA (no. JX-PSPC-434796) and JSPS KAKENHI Grant Number 15K00528 for their support in Japan. The work in Korea was supported by the National Institute of Environmental Research (NIER) of Korea, Ministry of Environment(MOE), as a "Public Technology Program based on Environmental Policy (RE201702180)". The DRAGON network deployments for the four DISCOVER-AQ missions were supported by the NASA Earth Venture - Suborbital program. We would like to thank the flight crew from both NASA B200 and $\mathrm{P}-3 \mathrm{~B}$ and the DISCOVER-AQ team members for their support during these missions. The Naval Research Laboratory staff participation was supported by the Office of Naval Research Code 322 and the NASA Interdisciplinary Science program. ORACLES contributions were funded under Earth Venture Suborbital-2 grant 13-EVS2-13-0028. The work of Qingyang Xiao and Yang Liu was partially supported by the NASA Applied Sciences Program (grant nos. NNX16AQ28G, NNX14AG01G, and NNX11AI53G). A special thank you goes to our in-country partners Abdulla Al Mandoos and the National Centre for Metrology \& Seismology for the $\mathrm{UAE}^{2}$ support, to Namibia University of Science and Technology for the DRAGON efforts in Namibia, The Indian Institute of Technology, Kanpur for TIGERZ support, Universiti Sains Malaysia for supporting the DRAGON-Penang campaign, 
and the National University of Singapore Center for Imaging, Sensing and Processing for DRAGON-Singapore. Finally, thanks to Lorraine Remer and the anonymous reviewer for their critical suggestions that strengthened this paper.

Edited by: Paola Formenti

Reviewed by: Lorraine Remer and one anonymous referee

\section{References}

Andrews, E., Ogren, J. A., Kinne, S., and Samset, B.: Comparison of AOD, AAOD and column single scattering albedo from AERONET retrievals and in situ profiling measurements, Atmos. Chem. Phys., 17, 6041-6072, https://doi.org/10.5194/acp17-6041-2017, 2017.

Anderson, T. L., Charlson, R. J., Winker, D. M., Ogren, J. A., and Holmén, K.: Mesoscale variations of tropospheric aerosols, J. Atmos. Sci., 60, 119-136, https://doi.org/10.1175/15200469(2003)060<0119:MVOTA>2.0.CO;2, 2003.

Artaxo, P., Gerab, F., Yamasoe, M. A., and Martins, J. V.: Fine mode aerosol composition at three long-term atmospheric monitoring sites in the Amazon Basin, J. Geophys. Res., 99, 22857-22868, https://doi.org/10.1029/94JD01023, 1994.

Ben-Ami, Y., Koren, I., Rudich, Y., Artaxo, P., Martin, S. T., and Andreae, M. O.: Transport of North African dust from the Bodélé depression to the Amazon Basin: a case study, Atmos. Chem. Phys., 10, 7533-7544, https://doi.org/10.5194/acp10-7533-2010, 2010.

Bergstrom, R. W., Pilewskie, P., Schmid, B., and Russell, P. B.: Estimates of the spectral aerosol single scattering albedo and aerosol radiative effects during SAFARI 2000, J. Geophys. Res., 108, 8474, https://doi.org/10.1029/2002JD002435, 2003.

Chand, D., Guyon, P., Artaxo, P., Schmid, O., Frank, G. P., Rizzo, L. V., Mayol-Bracero, O. L., Gatti, L. V., and Andreae, M. O.: Optical and physical properties of aerosols in the boundary layer and free troposphere over the Amazon Basin during the biomass burning season, Atmos. Chem. Phys., 6, 2911-2925, https://doi.org/10.5194/acp-6-2911-2006, 2006.

Che, H., Zhang, X. Y., Chen, H. B., Damiri, B., Goloub, P., Li, Z. Q.,Zhang, X. C.,Wei, Y., Zhou, H. G., Dong, F., Li, D. P., and Zhou, T. M.: Instrument calibration and aerosol optical depth validation of the China Aerosol Remote Sensing Network, J. Geophys. Res., 114, D03206, https://doi.org/10.1029/2008JD011030, 2009

Che, H., Zhang, X.-Y., Xia, X., Goloub, P., Holben, B., Zhao, H., Wang, Y., Zhang, X.-C., Wang, H., Blarel, L., Damiri, B., Zhang, R., Deng, X., Ma, Y., Wang, T., Geng, F., Qi, B., Zhu, J., Yu, J., Chen, Q., and Shi, G.: Ground-based aerosol climatology of China: aerosol optical depths from the China Aerosol Remote Sensing Network (CARSNET) 2002-2013, Atmos. Chem. Phys., 15, 7619-7652, https://doi.org/10.5194/acp15-7619-2015, 2015.

Chew, B. N., Campbell, J. R., Reid, J. S., Giles, D. M., Welton, E. J., Salinas, S. V., and Liew, S. C.: Tropical cirrus cloud contamination in sun photometer data, Atmos. Environ., 45, 6724-6731, https://doi.org/10.1016/j.atmosenv.2011.08.017, 2011.

Choi, M., Kim, J., Lee, J., Kim, M., Park, Y.-J., Jeong, U., Kim, W., Hong, H., Holben, B., Eck, T. F., Song, C. H., Lim, J.-H., and
Song, C.-K.: GOCI Yonsei Aerosol Retrieval (YAER) algorithm and validation during the DRAGON-NE Asia 2012 campaign, Atmos. Meas. Tech., 9, 1377-1398, https://doi.org/10.5194/amt9-1377-2016, 2016.

Corrigan, C. E., Roberts, G. C., Ramana, M. V., Kim, D., and Ramanathan, V.: Capturing vertical profiles of aerosols and black carbon over the Indian Ocean using autonomous unmanned aerial vehicles, Atmos. Chem. Phys., 8, 737-747, https://doi.org/10.5194/acp-8-737-2008, 2008.

d'Almeida, G. A.: A model for Saharan dust transport, J. Clim. Appl. Meteorol., 25, 903-916, 1986.

Dubovik, O. and King, M. D.: A flexible inversion algorithm for retrieval of aerosol optical properties from Sun and sky radiance measurements, J. Geophys. Res., 105, 20673-20696, 2000.

Dubovik, O., Smirnov, A., Holben, B. N., King, M. D., Kaufman, Y. J., Eck, T. F., and Slutsker, I.: Accuracy assessments of aerosol optical properties retrieved from AERONET sun and sky-radiance measurements, J. Geophys. Res., 105, 9791-9806, 2000.

Dubovik, O., Holben, B. N., Eck, T. F., Smirnov, A., Kaufman, Y. J., King, M. D., Tanre, D., and Slutsker, I.: Variability of absorption and optical properties of key aerosol types observed in worldwide locations, J. Atmos. Sci., 59, 590-608, 2002.

Dubovik, O., Sinyuk, A., Lapyonok, T., Holben, B. N., Mishchenko, M., Yang, P., Eck, T. F., Volten, H., Munoz, O., Veihelmann, B., van der Zande, W. J., Leon, J.-F., Sorokin, M., and Slutsker, I.: Application of spheroid models to account for aerosol particle nonsphericity in remote sensing of desert dust, J. Geophys. Res., 111, D11208, https://doi.org/10.1029/2005JD006619, 2006.

Eck, T. F., Holben, B. N., Reid, J. S., Dubovik, O., Smirnov, A., O'Neill, N. T., Slutsker, I., and Kinne, S.: Wavelength dependence of the optical depth of biomass burning, urban and desert dust aerosols, J. Geophys. Res., 104, 31333-31350, 1999.

Eck, T. F., Holben, B. N., Ward, D. E., Dubovik, O., Reid, J. S., Smirnov, A., Mukelabai, M. M., Hsu, N. C., O’Neill, N. T., and Slutsker, I.: Characterization of the optical properties of biomass burning aerosols in Zambia during the 1997 ZIBBEE field campaign, J. Geophys. Res., 106, 3425-3448, 2001.

Eck, T. F., Holben, B., Ward, D. E., and Slutsker, I.: Variability of biomass burning aerosol optical characteristics in southern Africa during the SAFARI 2000 dry season campaign and a comparison of single scattering albedo estimates from radiometric measurments, J. Geophys. Res., 108, 8477, https://doi.org/10.1029/2002JD002321, 2003.

Eck, T. F., Holben, B. N., Reid, J. S., Sinyuk, A., Dubovik, O., Smirnov, A., Giles, D., O’Neill, N. T., Tsay, S.-C., Ji, Q., Mandoos, A. Al, Khan, M. R., Reid, E. A., Schafer, J. S., Sorokin, M., Newcomb, W., and Slutsker, I.: Spatial and temporal variability of column-integrated aerosol optical properties in the southern Arabian Gulf and United Arab Emirates in summer, J. Geophys. Res., 113, D01204, https://doi.org/10.1029/2007JD008944, 2008.

Eck, T. F., Holben, B. N., Sinyuk, A., Pinker, R. T., Goloub, P., Chen, H., Chatenet, B., Li, Z., Singh, R. P., Tripathi, S. N., Reid, J. S., Giles, D. M., Dubovik, O., O’Neill, N. T., Smirnov, A., Wang, P., and Xia, X.: Climatological aspects of the optical properties of fine/coarse mode aerosol mixtures, J. Geophys. Res., 115, D19205, https://doi.org/10.1029/2010JD014002, 2010. 
Eck, T. F., Holben, B. N., Reid, J. S., Giles, D. M., Rivas, M. A., Singh, R. P., Tripathi, S. N., Bruegge, C. J., Platnick, S., Arnold, G. T., Krotkov, N. A., Cam, S. A., Sinyuk, A., Dubovik, O., Arola, A., Schafer, J. S., Artaxo, P., Smirnov, A., Chen, H., and Goloub, P.: Fog- and cloud-induced aerosol modification observed by the Aerosol Robotic Network (AERONET), J. Geophys. Res., 117, D07206, https://doi.org/10.1029/2011JD016839, 2012.

Eck, T. F., Holben, B. N., Reid, J. S., Arola, A., Ferrare, R. A., Hostetler, C. A., Crumeyrolle, S. N., Berkoff, T. A., Welton, E. J., Lolli, S., Lyapustin, A., Wang, Y., Schafer, J. S., Giles, D. M., Anderson, B. E., Thornhill, K. L., Minnis, P., Pickering, K. E., Loughner, C. P., Smirnov, A., and Sinyuk, A.: Observations of rapid aerosol optical depth enhancements in the vicinity of polluted cumulus clouds, Atmos. Chem. Phys., 14, 11633-11656, https://doi.org/10.5194/acp-14-11633-2014, 2014.

Esteve, A. R., Ogren, J. A., Sheridan, P. J., Andrews, E., Holben, B. N., and Utrillas, M. P.: Sources of discrepancy between aerosol optical depth obtained from AERONET and in-situ aircraft profiles, Atmos. Chem. Phys., 12, 2987-3003, https://doi.org/10.5194/acp-12-2987-2012, 2012.

Falkovich, A. H., Graber, E. R., Schkolnik, G., Rudich, Y., Maenhaut, W., and Artaxo, P.: Low molecular weight organic acids in aerosol particles from Rondônia, Brazil, during the biomassburning, transition and wet periods, Atmos. Chem. Phys., 5, 781797, https://doi.org/10.5194/acp-5-781-2005, 2005.

Flowers, E. C., McCormick, R. A., and Kurfis, K. R.: Atmospheric turbidity over the United States 1961-1966, J. Appl. Meteorol., 8, 955-962, 1969.

Fuzzi, S., Decesari, S., Facchini, M. C., Cavalli, F., Emblico, L, Mircea, M., Andreae, M. O., Trebs, I, Hoffer, A., Guyon, P., Artaxo, P., Rizzo, L. V., Lara, L. L., Pauliquevis, T., Maenhaut, W., Raes, N., Chi, X., Mayol-Bracero, O. L., Soto-Garcia, L. L., Claeys, M., Kourtchev, I., Rissler, J., Sweitlicki, E., Tagliavini, E., Schkolnik, G., Falkovich, A. H., Rudich, Y, Fisch, G., and Gatti, L. V.: Overview of the inorganic and organic composition of size-segregated aerosol in Rondônia, Brazil, from the biomassburning period to the onset of the wet season, J. Geophys. Res., 112, D01201, https://doi.org/10.1029/2005JD006741, 2007.

Garay, M. J., Kalashnikova, O. V., and Bull, M. A.: Development and assessment of a higher-spatial-resolution $(4.4 \mathrm{~km})$ MISR aerosol optical depth product using AERONETDRAGON data, Atmos. Chem. Phys., 17, 5095-5106, https://doi.org/10.5194/acp-17-5095-2017, 2017.

Giles, D. M., Holben, B. N., Tripathi, S. N., Eck, T. F., Newcomb, W. W., Slutsker, I., Dickerson, R. R., Thompson, A. M., Mattoo, S., Wang, S.-H., Singh, R. P., Sinyuk, A., and Schafer, J. S.: Aerosol properties over the Indo-Gangetic Plain: A mesoscale perspective from the TIGERZ experiment, J. Geophys. Res., 116, D18203, https://doi.org/10.1029/2011JD015809, 2011.

Giles, D. M., Holben, B. N., Eck, T. F., Sinyuk, A., Smirnov, A., Slutsker, I., Dickerson, R. R., Thompson, A. M., and Schafer, J. S.: An analysis of AERONET aerosol absorption properties and classifications representative of aerosol source regions, J. Geophys. Res., 117, D17203, https://doi.org/10.1029/2012JD018127, 2012.

Hashimoto, M., Nakajima, T., Dubovik, O., Campanelli, M., Che, H., Khatri, P., Takamura, T., and Pandithurai, G.: Development of a new data-processing method for SKYNET sky ra- diometer observations, Atmos. Meas. Tech., 5, 2723-2737, https://doi.org/10.5194/amt-5-2723-2012, 2012.

Hatakeyama, S., Ikeda, K., Hanaoka, S., Watanabe, I., Arakaki, T., Bandow, H., Sadanaga, Y., Kato, S., Kajii, Y., Zhang, D., Okuyama, K., Ogi, T., Fujimoto, T., Seto, T., Simizu, A., Sugimoto, N., and Takami, A.: Aerial observations of air masses transported from East Asia to the Western Pacific: Vertical structure of polluted air masses, Atmos. Environ., 97, 456-461, https://doi.org/10.1016/j.atmosenv.2014.02.040, 2014.

Haywood, J., Francis, P., Dubovik, O., Glew, M., and Holben, B.: Comparison of aerosol size distributions, radiative properties, and optical depths determined by aircraft observations and Sun photometers during SAFARI 2000, J. Geophys. Res., 108, 8471, https://doi.org/10.1029/2002JD002250, 2003.

Holben, B. N., Eck, T. F., and Fraser, R. S.: Temporal and spatial variability of aerosol optical depth in the Sahel region in relation to vegetation remote sensing, Int. J. Remote Sens., 12, 11471163, https://doi.org/10.1080/01431169108929719, 1991.

Holben, B. N., Setzer, A., Eck, T. F., Pereira, A., and Slutsker, I.: Effect of dry-season biomass burning on Amazon basin aerosol concentrations and optical properties, 1992-1994, J. Geophys. Res., 101, 19465-19481, 1996.

Holben, B. N., Eck, T. F., Slutsker, I., Tanre, D., Buis, J. P., Setzer, A., Vermote, E., Reagan, J. A., Kaufman, Y., Nakajima, T., Lavenu, F., Jankowiak, I., and Smirnov, A.: AERONET - A federated instrument network and data archive for aerosol characterization, Remote Sens. Environ., 66, 1-16, 1998.

Holben, B. N., Eck, T. F., Slutsker, I., Smirnov, A., Sinyuk, A., Schafer, J., Giles, D., and Dubovik, O.: Aeronet's Version 2.0 quality assurance criteria, Proc. SPIE, 6408, 64080Q, https://doi.org/10.1117/12.706524, 2006.

Ichoku, C., Chu, D. A., Mattoo, S., Kaufman, Y. J., Remer, L. A., Tanré, D., Slutsker, I., and Holben, B. N.: A spatio-temporal approach for global validation and analysis of MODIS aerosol products, Geophys. Res. Lett., 29, 8006, https://doi.org/10.1029/2001GL013206, 2002.

Jeong, U., Kim, J., Ahn, C., Torres, O., Liu, X., Bhartia, P. K., Spurr, R. J. D., Haffner, D., Chance, K., and Holben, B. N.: An optimal-estimation-based aerosol retrieval algorithm using OMI near-UV observations, Atmos. Chem. Phys., 16, 177-193, https://doi.org/10.5194/acp-16-177-2016, 2016.

Johnson, B. T., Christopher, S., Haywood, J. M., Osborne, S. R., McFarlane, S., Hsu, C., Salustro, C., and Kahn, R.: Measurements of aerosol properties from aircraft, satellite and groundbased remote sensing: a case-study from the Dust and Biomassburning Experiment (DABEX), Q. J. Roy. Meteor. Soc., 135, 922-934, 2009.

Kahn, R. A., Gaitley, B. J., Martonchik, J. V., Diner, D. J., Crean, K. A., and Holben, B.: Multiangle Imaging Spectroradiometer (MISR) global aerosol optical depth validation based on 2 years of coincident Aerosol Robotic Network (AERONET) observations, J. Geophys. Res., 110, D10S04, https://doi.org/10.1029/2004JD004706, 2005.

Kaku, K. C., Reid, J. S., O’Neill, N. T., Quinn, P. K., Coffman, D. J., and Eck, T. F.: Verification and application of the extended spectral deconvolution algorithm (SDA+) methodology to estimate aerosol fine and coarse mode extinction coefficients in the marine boundary layer, Atmos. Meas. Tech., 7, 3399-3412, https://doi.org/10.5194/amt-7-3399-2014, 2014. 
Kaneyasu, N., Yamamoto, S., Sato, K., Takami, A., Hayashi, M., Hara, K., Kawamoto, K., Okuda, T., and Hatakeyama, S.: Impact of long-range transport of aerosols on the $\mathrm{PM}_{2.5}$ composition at a major metropolitan area in the northern Kyushu area of Japan, Atmos. Environ., 97, 416-425, https://doi.org/10.1016/j.atmosenv.2014.01.029, 2014.

Kim, M., Kim, J., Jeong, U., Kim, W., Hong, H., Holben, B., Eck, T. F., Lim, J. H., Song, C. K., Lee, S., and Chung, C.-Y.: Aerosol optical properties derived from the DRAGON-NE Asia campaign, and implications for a single-channel algorithm to retrieve aerosol optical depth in spring from Meteorological Imager (MI) on-board the Communication, Ocean, and Meteorological Satellite (COMS), Atmos. Chem. Phys., 16, 1789-1808, https://doi.org/10.5194/acp-16-1789-2016, 2016.

Kinne, S., Lohmann, U., Feichter, J., Schulz, M., Timmreck, C., Ghan, S., Easter, R., Chin, M., Ginoux, P., Takemura, T., Tegen, I., Koch, D., Herzog, M., Penner, J., Pitari, G., Holben, B., Eck, T., Smirnov, A., Dubovik, O., Slutsker, I., Tanre, D., Torres, O., Mishchenko, M., Geogdzhayev, I., Chu, A., and Kaufman, Y.: Monthly averages of aerosol properties: A global comparison among models, satellite data and AERONET ground data, J. Geophys. Res., 108, 4634, https://doi.org/10.1029/2001JD001253, 2003.

Leahy, L. V., Anderson, T. L., Eck, T. F., and Bergstrom, R. W.: A synthesis of single scattering albedo of biomass burning aerosol over southern Africa during SAFARI 2000, Geophys. Res. Lett., 34, L12814, https://doi.org/10.1029/2007GL029697, 2007.

Li, Z., Eck, T., Zhang, Y., Zhang, Y., Li,D., Li, L., Xu, H., Hou, W., Lv, Y., Goloub, P., and Gu, X.: Observations of residual submicron fine aerosol particles related to cloud and fog processing during a major pollution event in Beijing, Atmos. Environ., 86, 187-192, 2014

Markham, B. L., Schafer, J. S., and Holben, B. N.: Atmospheric aerosol and water vapor characteristics over north central Canada during BOREAS, J. Geophys. Res., 103, 729-737, 1997.

Müller, D., Ansmann, A., Freudenthaler, V., Kandler, K., Toledano, C., Hiebsch, A., Gasteiger, J., Esselborn, M., Tesche, M., Heese, B., Althausen, D., Weinzierl, B., Petzold, A., and von Hoyningen-Huene, W.: Mineral dust observed with AERONET Sun photometer, Raman lidar, and in situ instruments during SAMUM 2006: Shapeindependent particle properties, J. Geophys. Res., 115, D07202, https://doi.org/10.1029/2009JD012520, 2010.

Müller, D., Lee, K.-H., Gasteiger, J., Tesche, M., Weinzierl, B., Kandler, K., Muller, T., Toledano, C., Otto, S., Althausen, D., and Ansmann, A.: Comparison of optical and microphysical properties of pure Saharan mineral dust observed with AERONET Sun photometer, Raman lidar, and in situ instruments during SAMUM 2006, J. Geophys. Res., 117, D07211, https://doi.org/10.1029/2011JD016825, 2012.

Munchak, L. A., Levy, R. C., Mattoo, S., Remer, L. A., Holben, B. N., Schafer, J. S., Hostetler, C. A., and Ferrare, R. A.: MODIS $3 \mathrm{~km}$ aerosol product: applications over land in an urban/suburban region, Atmos. Meas. Tech., 6, 1747-1759, https://doi.org/10.5194/amt-6-1747-2013, 2013.

Nakajima, T., Tonna, G., Rao, R., Boi, P., Kaufman, Y. J., and Holben, B. N.: Use of sky brightness measurements from ground for remote sensing of particulate polyispersions, Appl. Optics, 35, 2672-2686, 1996.
Nakata, M., Sano, I., Mukai, S., and Holben, B. N.: Spatiotemporal variations in atmospheric aerosols in East Asia: Identifying local pollutants and transported Asian aerosols in Osaka, Japan using DRAGON, Atmos. Chem. Phys. Discuss., https://doi.org/10.5194/acp-2016-182, 2016.

O’Neill, N. T., Eck, T. F., Smirnov, A., Holben, B. N., and Thulasiraman, S.: Spectral discrimination of coarse and fine mode optical depth, J. Geophys. Res., 108, 4559, https://doi.org/10.1029/2002JD002975, 2003.

O’Neill, N. T., Eck, T. F., Reid, J. S., Smirnov, A., and Pancrati, O.: Coarse mode optical information retrievable using VIS to SWIR high-frequency sunphotometry; application to UAE2 data, J. Geophys. Res., 113, D05212, https://doi.org/10.1029/2007JD009052, 2008.

Osborne, S. R., Johnson, B. T., Haywood, J. M., Baran, A. J., Harrison, M. A. J., and McConnell, C. L.: Physical and optical properties of mineral dust aerosol during the Dust and Biomass-burning Experiment, J. Geophys. Res., 113, D00C03, https://doi.org/10.1029/2007JD009551, 2008.

Prospero, J. and Carlson, T.: Vertical and areal distribution of Saharan dust over the western equatorial North Atlantic Ocean, J. Geophys. Res., 77, 5255-5265, 1972.

Randles, C. A., da Silva, A. M., Buchard, V., Colarco, P. R., Darmenov, A., Govindaraju, R., Smirnov, A., Holben, B., Ferrare, R., Hair, J., Shinozuka, Y., and Flynn, C. J.: The MERRA-2 Aerosol Reanalysis, 1980-onward, Part I: System Description and Data Assimilation Evaluation, J. Climate, 30, 6823-6850, https://doi.org/10.1175/jcli-d-16-0609.1, 2017.

Ramanathan, V., Crutzen, P. J., Lelieveld, J., Mitra, A. P., Althausen, D., Anderson, J., Andreae, M. O., Cantrell, W., Cass, G. R., Chung, C. E., Clarke, A. D., Coakley, J. A., Collins, W. D., Conant, W. C., Dulac, F., Heintzenberg, J., Heymsfield, A. J., Holben, B., Howell, S., Hudson, J., Jayaraman, A., Kiehl, J. T., Krishnamurti, T. N., Lubin, D., McFarquhar, G., Novakov, T., Ogren, J. A., Podgorny, I. A., Prather, K., Priestley, K., Prospero, J. M., Quinn, P. K., Rajeev, K., Rasch, P., Rupert, S., Sadourny, R., Satheesh, S. K., Shaw, G. E., Sheridan, P., and Valero, F. P. J.: The Indian Ocean Experiment: An Integrated Assessment of the Climate Forcing and Effects of the Great Indo-Asian Haze, J. Geophys. Res.-Atmos., 106, 28371-28399, 2001.

Reid, J. S., Jonsson, H. H., Maring, H. B., Smirnov, A., Savoie, D. L., Cliff, S. S., Reid, E. A., Meier, M. M., Dubovik, O., and Tsay, S.-C.: Comparison of size and morphological measurements of coarse mode dust particles from Africa, J. Geophys. Res., 108, 8593, https://doi.org/10.1029/2002JD002485, 2003.

Reid, J. S., Koppmann, R., Eck, T. F., and Eleuterio, D. P.: A review of biomass burning emissions part II: intensive physical properties of biomass burning particles, Atmos. Chem. Phys., 5, 799825, https://doi.org/10.5194/acp-5-799-2005, 2005.

Reid, J. S., Brooks, B., Crahan, K. K., Hegg, D. A., Eck, T. F., O'Neill, N., de Leeuw, G., Reid, E. A., and Anderson, K. D.: Reconciliation of coarse mode sea-salt aerosol particle size measurements and parameterizations at a subtropical ocean receptor site, J. Geophys. Res., 111, D02202, https://doi.org/10.1029/2005JD006200, 2006.

Reid, J. S., Piketh, S., Burger, R., Ross, K., Jensen, T., Bruintjes, R., Walker, A., Al Mandoos, A., Miller, S., Hsu, C., Kuciauskas, A., and Westphal, D. L.: An overview of UAE2 flight operations: Observations of summertime atmospheric thermodynamic and 
aerosol profiles of the southern Arabian Gulf, J. Geophys. Res., 113, D14213, https://doi.org/10.1029/2007JD009435, 2008a.

Reid, J. S., Reid, E. A., Walker, A., Piketh, S., Cliff, S., Al Mandoos, A., Tsay, S., and Eck, T. F.: Dynamics of southwest Asian dust particle size characteristics with implications for global dust research, J. Geophys. Res., 113, D14212, https://doi.org/10.1029/2007JD009752, 2008b.

Reid, J. S., Hyer, E. J., Johnson, R., Holben, B. N., Yokelson, R. J., Zhang, J., Campbell, J. R., Christopher, S. A., Di Girolamo, L., Giglio, L., Holz, R. E., Kearney, C., Miettinen, J., Reid, E. A., Joseph Turk, F., Wang, J., Xian, P., Zhao, G., Balasubramanian, R., Chew, B. N., Janai, S., Lagrosas, N., Lestari, P., Lin, N.-H., Mahmud, M., Nguyen, X. A., Norris, B., Oahn, T. K., Oo, M., Salinas, S. V., Welton, E. J., and Liew, S. C.: Observing and understanding the Southeast Asian aerosol system by remote sensing: An initial review and analysis for the Seven Southeast Asian Studies (7SEAS) program, Atmos. Res., 122, 403-468, 2013.

Reid, J. S., Kuehen, R. E., Holz, R. E., Eloranta, E. W., Kaku, K. C., Kuang, S., Newchurch, M. J., Thompson, A. M., Trepte, C., R., Zhang, J., Atwood, S. A., Hand, J. L., Holben, B. N., Minnis, P., and Posselt, D. J.: Ground-based High Spectral Resolution Lidar observation of aerosol vertical distribution in the summertime Southeast United States, J. Geophys. Res.-Atmos., 122, 2970-3004, https://doi.org/10.1002/2016JD025798, 2017.

Remer, L. A., Gasso, S., Hegg, D. A., Kaufman, Y. J., and Holben, B. N.: Urban/industrial aerosol: Ground-based Sun/sky radiometer and airborne in situ measurements, J. Geophys. Res., 102, 16849-16859, 1997.

Remer, L. A., Tanré, D., Kaufmann, Y. J., Ichoku, C., Mattoo, S., Levy, R., Chu, D. A., Holben, B., Dubovik, O., Smirnov, A., Martins, J. V., Li, R.-R., and Ahmad, Z.: Validation of MODIS aerosol retrieval over ocean, Geophys. Res. Lett., 29, MOD3-1MOD3-4, https://doi.org/10.1029/2001GL013204, 2002.

Rubin, J. I., Reid, J. S., Hansen, J. A., Anderson, J. L., Holben, B. N., Xian, P., Westphal, D. L., and Zhang, J.: Assimilation of AERONET and MODIS AOT observations using variational and ensemble data assimilation methods and its impact on aerosol forecasting skill, J. Geophys. Res.-Atmos., 122, 49674992, https://doi.org/10.1002/2016JD026067, 2017.

Russell, P. B., Kacenelenbogen, M., Livingston, J, M., Hasekamp, O. P., Burton, S. P., Schuster, G. L., Johnson, M. S., Knobelspiesse, K. D., Redemann, J., Ramachandran, S., and Holben, B.: A Multi-Parameter Aerosol Classification Method and its Application to Retrievals from Spaceborne Polarimetry, J. Geophys. Res., 119, 9838-9863, https://doi.org/10.1002/2013JD021411, 2014.

Sayer, A. M., Hsu, N. C., Bettenhausen, C., Ahmad, Z., Holben, B. N., Smirnov, A., Thomas, G. E., and Zhang, J.: SeaWiFS Ocean Aerosol Retrieval (SOAR): Algorithm, validation, and comparison with other data sets, J. Geophys. Res.-Atmos., 117, D03206, https://doi.org/10.1029/2011JD016599, 2012.

Sano, I.: Aerosol properties over Japan by sun/sky photometry during APEX-E3, Proc. SPIE 5235, Remote Sensing of Clouds and the Atmosphere VIII, 627, https://doi.org/10.1117/12.510927, 2004.

Sano, I., Mukai, S., Nakata, M., and Holben, B. N.: Regional and local variations in atmospheric aerosols using ground-based sun photometry during Distributed Regional Aerosol Gridded Observation Networks (DRAGON) in 2012, Atmos. Chem. Phys.,
16, 14795-14803, https://doi.org/10.5194/acp-16-14795-2016, 2016.

Sawamura, P., Müller, D., Hoff, R. M., Hostetler, C. A., Ferrare, R. A., Hair, J. W., Rogers, R. R., Anderson, B. E., Ziemba, L. D., Beyersdorf, A. J., Thornhill, K. L., Winstead, E. L., and Holben, B. N.: Aerosol optical and microphysical retrievals from a hybrid multiwavelength lidar data set - DISCOVER-AQ 2011, Atmos. Meas. Tech., 7, 3095-3112, https://doi.org/10.5194/amt-7-30952014, 2014.

Sawamura, P., Moore, R. H., Burton, S. P., Chemyakin, E., Müller, D., Kolgotin, A., Ferrare, R. A., Hostetler, C. A., Ziemba, L. D., Beyersdorf, A. J., and Anderson, B. E.: HSRL-2 aerosol optical measurements and microphysical retrievals vs. airborne in situ measurements during DISCOVER-AQ 2013: an intercomparison study, Atmos. Chem. Phys., 17, 7229-7243, https://doi.org/10.5194/acp-17-7229-2017, 2017.

Schafer, J. S., Eck, T. F., Holben, B. N., Thornhill, K. L., Anderson, B. E., Sinyuk, A., Giles, D. M., Winstead, E. L., Ziemba, L. D., Beyersdorf, A. J., Kenny, P. R., Smirnov, A., and Slutsker, I.: Intercomparison of aerosol single-scattering albedo derived from AERONET surface radiometers and LARGE in situ aircraft profiles during the 2011 DRAGON-MD and DISCOVER-AQ experiments, J. Geophys. Res., 119, 74397452, https://doi.org/10.1002/2013JD021166, 2014.

Schafer, J. S., Eck, T. F., Holben, B. N., Artaxo, P., and Duarte, A. F.: Characterization of the optical properties of atmospheric aerosols in Amazônia from long-term AERONET monitoring (1993-1995 and 1999-2006), J. Geophys. Res., 113, D04204, https://doi.org/10.1029/2007JD009319, 2008.

Schafer, J. S., Eck, T. F., Ziemba, L. D., Holben, B. N., Anderson, B. E., Sinyuk, A., Thornhill, K. L., Giles, E. L., Winstead, A. J., Beyersdorf, A. J., Slutsker, I., and Smirnov, A.: Intercomparison of Aerosol Volume Size Distributions derived from surface radiometers and in-situ aircraft profiles during four, DISCOVERAQ campaigns, in preparation, 2018.

Seo, S., Kim, J., Lee, H., Jeong, U., Kim, W., Holben, B. N., Kim, S.-W., Song, C. H., and Lim, J. H.: Estimation of $\mathrm{PM}_{10}$ concentrations over Seoul using multiple empirical models with AERONET and MODIS data collected during the DRAGON-Asia campaign, Atmos. Chem. Phys., 15, 319-334, https://doi.org/10.5194/acp-15-319-2015, 2015.

Sessions, W. R., Reid, J. S., Benedetti, A., Colarco, P. R., da Silva, A., Lu, S., Sekiyama, T., Tanaka, T. Y., Baldasano, J. M., Basart, S., Brooks, M. E., Eck, T. F., Iredell, M., Hansen, J. A., Jorba, O. C., Juang, H.-M. H., Lynch, P., Morcrette, J.-J., Moorthi, S., Mulcahy, J., Pradhan, Y., Razinger, M., Sampson, C. B., Wang, J., and Westphal, D. L.: Development towards a global operational aerosol consensus: basic climatological characteristics of the International Cooperative for Aerosol Prediction MultiModel Ensemble (ICAP-MME), Atmos. Chem. Phys., 15, 335362, https://doi.org/10.5194/acp-15-335-2015, 2015.

Smirnov, A., Holben, B. N., Eck, T. F., Dubovik, O., and Slutsker, I.: Cloud screening and quality control algorithms for the AERONET database, Remote Sens. Environ., 73, 337-349, 2000.

Smirnov, A., Holben, B. N., Dubovik, O., Frouin, R., Eck, T. F., and Slutsker, I.: Maritime component in aerosol optical models derived from Aerosol Robotic Network data, J. Geophys. Res., 108, 4033, https://doi.org/10.1029/2002JD002701, 2003. 
Swap, R. J., Annegarn, H. J., Suttles, J. T., King, M. D., Platnick, S., Privette, J. L., and Scholes, R. J.: Africa burning: A thematic analysis of the Southern African Regional Science Initiative (SAFARI 2000), J. Geophys. Res., 108, 8465, https://doi.org/10.1029/2003JD003747, 2003.

Takami, A., Mayama, N., Sakamoto, T., Ohishi, K., Irei, S., Yoshino, A., Hatakeyama, S., Murano, K., Sadanaga, Y., Bandow, H., Misawa, K., and Fujii, M.: Structural analysis of aerosol particles by microscopic observation using a timeof-flight secondary ion mass spectrometer, J. Geophys. Res.Atmos., 118, 6726-6737, https://doi.org/10.1002/jgrd.50477, 2013.

Tan, F., San Lim, H., Abdullah, K., Yoon, T. L., and Holben, B.: AERONET data-based determination of aerosol types, Atmospheric Pollution Research, 6, 682-695, https://doi.org/10.5094/APR.2015.077, 2015a.

Tan, F., Lim, H. S., Abdullah, K., Yoon, T. L., and Holben, B.: Monsoonal variations in aerosol optical properties and estimation of aerosol optical depth using ground-based meteorological and air quality data in Peninsular Malaysia, Atmos. Chem. Phys., 15, 3755-3771, https://doi.org/10.5194/acp-15-3755-2015, 2015 b.

Toledano, C., Wiegner, M., Grob, S., Freudenthaler, V., Gasteiger, J., Muller, D., Muller, D., Schladitz, A., Weinzierl, B., Torres, B., and O'Neill, N. T.: Optical properties of aerosol mixtures derived from sun-sky radiometry during SAMUM-2, Tellus B, 63, 635648, https://doi.org/10.1111/j.1600-0889.2011.00573.x, 2011.

Toon, O. B., Maring, H., Dibb J., Ferrare, R., Jacob, D. J., Jensen, E. J., Luo, Z. J., Mace, G. G., Pan, L. L., Pfister, L., Rosenlof, K. H., Redemann, J., Reid, J. S., Singh, H. B., Thompson, A. M., Yokelson, R., Minnis, P., Chen, G., Jucks, K. W., and Pszenny, A.: Planning, implementation, and scientific goals of the Studies of Emissions and Atmospheric Composition, Clouds and Climate Coupling by Regional Surveys (SEAC4RS) field mission, J. Geophys. Res.-Atmos., 121, 49675009, https://doi.org/10.1002/2015JD024297, 2016.
Warneke, C., Trainer, M., de Gouw, J. A., Parrish, D. D., Fahey, D. W., Ravishankara, A. R., Middlebrook, A. M., Brock, C. A., Roberts, J. M., Brown, S. S., Neuman, J. A., Lerner, B. M., Lack, D., Law, D., Hübler, G., Pollack, I., Sjostedt, S., Ryerson, T. B., Gilman, J. B., Liao, J., Holloway, J., Peischl, J., Nowak, J. B., Aikin, K. C., Min, K.-E., Washenfelder, R. A., Graus, M. G., Richardson, M., Markovic, M. Z., Wagner, N. L., Welti, A., Veres, P. R., Edwards, P., Schwarz, J. P., Gordon, T., Dube, W. P., McKeen, S. A., Brioude, J., Ahmadov, R., Bougiatioti, A., Lin, J. J., Nenes, A., Wolfe, G. M., Hanisco, T. F., Lee, B. H., LopezHilfiker, F. D., Thornton, J. A., Keutsch, F. N., Kaiser, J., Mao, J., and Hatch, C. D.: Instrumentation and measurement strategy for the NOAA SENEX aircraft campaign as part of the Southeast Atmosphere Study 2013, Atmos. Meas. Tech., 9, 3063-3093, https://doi.org/10.5194/amt-9-3063-2016, 2016.

Washington, R., Todd, M. C., Engelstaedter, S., Mbainayel, S., and Mitchell, F.: Dust and the low-level circulation over the Bodélé Depression, Chad: Observations from BoDEx 2005, J. Geophys. Res., 111, D03201, https://doi.org/10.1029/2005JD006502, 2006.

World Health Orgnization: Hazard Prevention and Control in the Work Environment: Airborne Dust WHO/SDE/OEH/99.14, 1999.

Xiao, Q., Zhang, H., Choi, M., Li, S., Kondragunta, S., Kim, J., Holben, B., Levy, R. C., and Liu, Y.: Evaluation of VIIRS, GOCI, and MODIS Collection 6 AOD retrievals against ground sunphotometer observations over East Asia, Atmos. Chem. Phys., 16, 1255-1269, https://doi.org/10.5194/acp-16-1255-2016, 2016.

Zuidema, P., Redemann, J., Haywood, J., Wood, R., Piketh, S., Hipondoka, M., and Formenti, P.: Smoke and Clouds above the Southeast Atlantic: Upcoming Field Campaigns Probe Absorbing Aerosol's Impact on Climate, B. Am. Meteorol. Soc., 97, 1131-1135, https://doi.org/10.1175/BAMS-D-15-00082.1, 2016. 